\title{
DESCRIPTIONS OF NEW LEPIDOPTERA, CHIEFLY FROM MEXICO.
}

\author{
By. Harrison G. Dyar, \\ Custodian of Lepidoptera, United States National Museum.
}

The following descriptions are in continuation of those already published on the Mexican fauna. ${ }^{1}$ A few species are included from nearby regions, or which are especially allied to Mexican species here mentioned:

\section{Family NYMPHALIDA. \\ Genus PHYCIODES Hübner.}

PHYCIODES NATALCES, new species.

Fore wing with an emargination below the middle of the outer margin; black, the base variegated with rufous; spots buff; a small one in the cell, followed by a vertical rufous streak; a curved row of three beyond the cell, with an obscure one above near costa; a square spot between veins 2 and 3 with a little spot above and below, followed by a little rufous spot; two spots below vein 2, one near its origin, the other outwardly placed; another similarly placed spot above vein 4; a faint submarginal row of crescents, of which only the two central ones are distinct. Hind wing with the base variegated with rufous streaks, two curved ones on the cell being prominent; an outer mesial buff band, narrowly cut by the veins, not reaching costa or margin; beyond it a narrow rufous line, cut by the veins; a submarginal row of narrow crescents; fringe crenulate, whitish tipped. Beneath the basal third of fore wing is whitish, variegated with brown lines, with an irregular curved black line shortly before the termination of the pale arc; outer two-thirds of the ground black; a broad pale bar in end of cell with digitate outer margin; spots repeated, enlarged, white, scarcely cut by the veins; a narrow pale line joining the large median spot to costa; termen shaded with whitish and rufous, cut by black shades subapically and

\footnotetext{
1 Proc. U. S. Nat. Mus., vol. 38, 1910, pp. 229-273; Proc. U. S. Nat. Mus., vol. 42, 1912, pp. 39-106.
} 
at tornus. Hind wing with the ground whitish, tinged with rufous; base variegated with brown and rufous lines; a narrow mesial black line across the wing in irregular course, separating the basal variegated area from the outer one; a submarginal row of broad crescents, edged within by black and followed by the brown termen, obscured by a black cloud between veins 5 and 6 ; an outer mesial row of black spots, faintly surrounded by rufous; a black cloud on costa in the mesial area. Expanse, $39 \mathrm{~mm}$.

Type.-Female, No. 14487, U.S.N.M., Rascon, San Luis Potosi, Mexico, August, 1911 (R. Müller).

\section{Family HESPERIID无.}

\section{Genus THESPIEUS Godman and Salvin.}

\section{THESPIEUS DALMANI GUERRERONIS, new subspecies.}

Differs from Thespieus dalmani Latreille principally in the size of the brown spot on the hind wings below, which is large, triangular, its lower angle reaching as far as the end of the inner white spot.

Cotypes.-Three males, No. 14488, U.S.N.M., Baleas, Gurrero, 1,500 feet, August, 1906; Iguala, Guerrero, 2,400 feet, June, 1906; Naranjo, Guerrero, Mexico, 3,000 feet, August, 1906 (W. Schaus).

THESPIEUS CACAJO, new species.

Bronzy black above, yellowish shaded at the bases of the wings; spots yellowish hyaline; discal spot square, constricted centrally; three small wedge-shaped spots below the costa at outer fourth; three oblique spots below, the upper two quadrate, middle one large, lower one wedge-shaped; male with a long narrow brand, cut into two segments by vein 2 . Hind wing with three spots on the disk, divided only by the veins, narrowing toward apex and without any following yellow shades. Beneath the spots are repeated; fore wing with a broad ferruginous yellow stain beyond the subapical spots, followed by a purplish line; hind wing with mottled purplish shading across the disk within the middle; a large brown triangular spot below the hyaline spots, edged narrowly with purplish; three ferruginous-red spots beyond the hyaline spots, separated by the veins. Expanse, 36-40 mm.

Cotypes.-Two males, one female, No. 14489, U.S.N.M., Naranjo, Guerrero, Mexico, 3,000 feet, August, 1906 (W. Schaus); Cuernavaca, Mexico, August, 1906 (W. Schaus).

THESPIEUS ZAOVINIA, new species.

Black, the wings a little bronzy, especially toward base; spots whitish hyaline; discal spot large, strongly constricted; three small subapical elongate quadrate spots, the middle one moved inward 
out of line; three lower outer spots, the upper two quadrate, middle one large, lower one minute. Hind wing with five small spots across the disk in an irregular row, the upper two separated only by a vein. Beneath the markings are repeated; the hind wings are washed with dense gray irrorations; there is a whitish costal spot beyond the middle, not shown above, two spots within it across the disk and another subbasal below vein 8 . Expanse, $35 \mathrm{~mm}$.

Type.-One male, No. 14490, U.S.N.M., Tehuacan, Mexico, August, 1911 (R. Müller).

This species is close to T. ovinia Hewitson, but the subapical spots of the fore wing are not in line and the spots on the hind wing below are narrow.

\section{Genus AMBLYSCIRTES Scudder.}

AMBLYSCIRTES TUTOLIA, new species.

Black, slightly bronzy, the fringes pale outwardly; the fore wing has a small elliptical yellowish spot in the outer lower part of the cell; three small costo-subapical spots and a small spot below above vein 3 ; male with a narrow oblique black brand. Beneath the spots are repeated, increased in number, the fore wing having a row of seven beyond the cell-spot, the fourth and fifth projected outward, the seventh an oblique dash; brand repeated, surrounded by black; a broad light yellow shade above vein 1, beginning at the middle of the wing and spreading outwardly. Hind wing below brownish black, with eight spots in a broad circle and a central one in the cell, all small, whitish, elliptical. Expanse, $32 \mathrm{~mm}$.

Type-One male, No. 14491, U.S.N.M., Sierra de Guerrero, Mexico, August, 1911 (R. Müller).

\section{Genus STAPHYLUS Godman and Salvin.}

STAPHYLUS HOLAPHEGGES, new species.

Black above, slightly bronzy, without markings; brown-black below. Palpi grayish beneath, having white scales intermixed; abdomen with the venter gray with central black line. Expanse, $22 \mathrm{~mm}$.

Cotypes.-Five specimens, No. 14492, U.S.N.M., Misantla, Mexico, July, 1911 (R. Müller).

\section{Genus ARGOPTERON Watson.}

\section{ARGOPTERON DIVIDUUM, new species.}

Black; fore wings with yellow-hyaline spots; a square one in the end of the cell separated by the median vein from a larger one below, of which the lower portion is cut by vein 2 ; three small costosubapical spots, fused, separated only by the veins; a small spot below above vein 3 . Hind wing with a large spot beyond the cell, 
its lower tip cut by a vein; a wedge-shaped spot below, succeeded by a smaller one; fringe irregularly marked with yellow. Beneath the fore wing is grayish black, the spots repeated, the apical margin washed with bronzy reddish, cut by dark veins. Hind wing all washed with bronzy reddish, the spots repeated, yellow and in addition a long one in base of cell and subcostal one above it; a row of blackish spots subcostally outwardly, continued in a faint double submarginal row around the wing; subterminal area a little lighter and cut by darker veins. Expanse, 26-30 mm.

Cotypes.-Six specimens, No. 14493, U.S.N.M., Sierra de Guerrero, Mexico, August, 1911 (R. Müller); Iguala, Guerrero, Mexico, 2,400 feet, June, 1906 (W. Schaus); Naranjo, Guerrero, Mexico, 3,000 feet, August, 1906 (W. Schaus).

\section{Genus MEGATHYMUS Scudder.}

MEGATHYMUS RETHON, new species.

Black, with a slight blue luster; fore wing with one small, faint, whitish subcosto-subapical spot-no other markings; fringe checkered black and white. Hind wing with the fringe white, narrowly cut by black at the ends of the veins, the white color spreading up on the margin of the wing, especially centrally. Fore wing beneath as above, except that there are three closely crowded costo-subapical whitish spots. The hind wings have a slight grayish cast, especially submarginally in faint spots and terminally, the fringe white, cut by black as on the upper side, but there is a narrow terminal black line distinctly separating the fringe, which is not present above. Expanse, $50 \mathrm{~mm}$.

Type.-No. 14494, U.S.N.M., Sierra de Guerrero, Mexico, August, 1911 (R. Müller).

\section{Family SATURNIIDÆ.}

\section{Genus HYLESIA Hübner.}

HYLESIA SUBAUREA Schaus.

Hylesia subaurea Schaus, Journ. N. Y. Ent. Soc., vol. 8, 1900, p. 227, female. Hylesia coadjutor Dyar, Journ. N. Y. Ent. Soc., vol. 15, 1907, p. 51, male.

$H$. coadjutor is probably the male of $H$. subaurea. The sexes in this genus are often very dissimilar, but there is a certain general resemblance between these two types which suggests that they may be conspecific. Both come from the same locality.

HYLESIA IOLA, new species.

Male.-Carneous brown; thorax darker and more ocherous, the front, orbits, and legs shaded with crimson; abdomen black above, with long ocherous hairs. Fore wing with two rigid lines, a little curved, brown with inner whitish edging, shortly and sharply bent 
at costa; a faint dark discal cloud; traces of a pale waved submarginal line. Hind wing crimson tinted on the disk, with a discal dull crimson thick annulus; traces of a dull crimson submarginal band. Expanse, $45 \mathrm{~mm}$.

Female.-Thorax above and below and both wings dull crimson; abdomen black above, ocher brown beneath. Fore wing with traces of the outer band, of which the pale inner edging is most distinct; traces of the pale waved submarginal line. Hind wing with discal small dull crimson annulus faintly shown, much smaller than in the male. Expanse, $54 \mathrm{~mm}$.

Cotypes.-Male and female, No. 14689, U.S.N.M., Mexico City, Mexico, December, 1909 (R. Müller).

\section{HYLESIA COINOPUS, new species.}

Purplish brown; body parts ocher brown; feet concolorous, with out any crimson tint. Both wings with rounded dark discal marks, diffused but distinct; an outer pale band, wavy in the male, straighter in the female, faint on the hind wing in the male and absent in the female; traces of a wavy submarginal whitish line. Expanse, $35-48 \mathrm{~mm}$.

Cotypes.-Male and female, No. 14690, U.S.N.M., Coatepec, Mexico, August, 1911 (W. Gugelmann).

Larva.-Head rounded, higher than wide, smooth, shining, mahogany brown, the sutures paler; secondary hairs white, rather numerous below, but fine and not conspicuous. Body cylindrical, smaller in front, yellowish, thickly dotted with black, leaving wavy addorsal and subdorsal, and straight lateral and subventral lines of the ground color and forming broken narrow transverse black lines deep in the segmental incisures. Venter and bases of feet pale; feet reddish, thoracic feet pale brown. Spines with the shafts weak and soft, pale, subdorsal row with single median spine on joints 12 and 13, those on joint 2 long but like the others in color and structure; lateral row about like the subdorsal; subventral row shorter.

The adult resembles $H$. continua Walker, as determined by $\mathbf{W}$. Schaus, but is larger, more rosy, and the whitish transverse lines are much more distinct.

\section{Family CITHERONIID无.}

\section{Genus SISPHYNX Hübner.}

\section{SISPHYNX MODENA, new species.}

Center of thorax and more or less of dorsum of abdomen dark ocher; patagia pale purplish; body below creamy white. Fore wing yellow with orange tint, very slightly freckled with brown; inner line curved, outer oblique and straight from apex to middle of inner margin, both pale brown; one or two small white discal dots, surrounded 
by a brownish cloud; in the male the basal and terminal spaces are filled in with pale purplish. Hind wing pale yellow with a dark crimson patch on basal half of inner margin, in the male forming also a small spot at end of cell. Expanse, male $54 \mathrm{~mm}$; female $70 \mathrm{~mm}$.

Cotypes.-Three males, one female, No. 15218, U.S.N.M., Cuernavaca, Mexico, June, 1906 (W. Schaus), June, 1912 (R. Müller).

\section{Family SYNTOMIDÆ.}

\section{Genus EUROTA Walker.}

\section{EUROTA DESCINTES, new species.}

Black; collar with white point at side; fore coxæ marked with white; fore femora fringed with crimson; abdomen with lateral row of elliptical white spots, and a small sublateral row, the ventral valve of the male narrowly edged with white, anal tuft crimson; antennæ with white at the tip; fore wing with the costa swollen at base, containing an elongate whitish hyaline spot; a white point at base; a quadrate spot below the costal mark, two near the middle of the wing and a row of four pyriform ones before apex. Hind wing with a spot near base and a large quadrate one outwardly, with a small spot below it. Expanse, 46-51 mm.

Cotypes.-Five males, five females, No. 14691, U.S.N.M., Morelos, Mexico, 7,000 feet, 1906 (W. Schaus).

Near E. vulcanus Walker, but the fore legs only with a red fringe, the white markings smaller throughout and the swelling at base of costa larger.

\section{Family LITHOSIIDA.}

\section{Genus PTYCHOGLENE Felder.}

PTYCHOGLENE STENODORA, new species.

Black, with slight blue reflection; fore wing with a vermillion subcostal stripe, widening outwardly from base and terminating a little obliquely halfway between cell and margin. Hind wing with a costal stripe terminating before apex. Beneath the whole of the fore wing is red except a narrow costal stripe and broad outer margin; hind wing with the red area only a little wider than above. Expanse, $36 \mathrm{~mm}$.

Cotypes.-Two females, No. 14300, U.S.N.M., Tehuacan, Mexico, June, 1910 (R. Müller).

\section{Family ARCTIID无.}

\section{Genus EUCHAETIAS Lyman.}

EUCHAETIAS CRESSIDA, new species.

Head pale gray in front, orange on the vertex. Abdomen orange above, white with a gray tint below, with dorsal and lateral rows of 
black spots. Thorax white with a gray tint. Wings white, shining, the fore wing gray beneath. Expanse, $33 \mathrm{~mm}$.

Type.-One male, No. 14461, U.S.N.M., Cerritos, San Luis Potosi, August, 1911 (R. Müller).

EUCHAETIAS RHADIA, new species.

Dark gray; abdomen crimson above with small dorsal black spots and lateral dashes, whitish below in the male, gray in the female. Fore wing gray, with a very slight brown tint and hardly any white dusting. Hind wing darker, purer gray in the male, dark, almost blackish in the female. Expanse, 32-42 mm.

Cotypes.-Two males, one female, No. 14462, U.S.N.M., Mexico? (J. Doll); Jalapa, Mexico (Schaus collection).

This appears to be Hampson's subspecies 1 of E. expressa H. Edwards, but I am inclined to regard the form as specifically distinct.

\section{EUCHAETIAS EPAGOGA, new species.}

Light gray, the neck pink, the fore coxæ touched with pink. Abdomen crimson above with dorsal and lateral black spots, white below in the male, gray in the female, Fore wing very light gray, almost white in ground, but thickly dusted with gray scales, leaving an indistinct outer pale band. Hind wing pale gray in the male, though a little darker than the fore wing, still darker in the female and showing considerably darker than the fore wing in that sex. Expanse, 35-42 mm.

Cotypes.-Two males, one female, No. 14463, U.S.N.M., Tehuacan, Mexico, August, 1911, September, 1910 (R. Müller); Oaxaca, Mexico (Schaus collection).

This is not quite so light in color as E. mitis Schaus (which is Hampson's subspecies 2 of E. expressa H. Edwards), which has the hind wings nearly pure white in the male, but the fore wings are less densely powdered than in mitis and consequently appear lighter. E. mitis occurs in Costa Rica.

\section{Genus CALIDOTA Dyar.}

CALIDOTA CALOSOMA, new species.

Thorax light yellow, the patagia streaked with ocher, disk crimson; vertex of head ocher, front fuscous. Abdomen crimson at the base, then slaty gray, the anal tuft ocher; pleuræ and pectus crimson; legs slate gray; antennæ nearly black. Wings rather thinly scaled and semitranslucent; fore wing uniform gray; hind wing a little paler and decidedly translucent over the discal area. Expanse, $46 \mathrm{~mm}$.

Type.-One male, No. 14460, U.S.N.M., Orizaba, Mexico, September, 1911 (R. Müller). 


\section{Genus AMMALO Walker.}

AMMALO TENEROSA, new species.

White, the head, fore coxæ, collar and base of costa of fore wings ocherous; fore tibiæ gray; abdomen ocher above except at base with a row of small dorsal black spots and smaller lateral ones. Expanse, $31 \mathrm{~mm}$.

Type.-Male, No. 15219, U.S.N.M., Misantla, Mexico, May, 1912 (R. Müller).

\section{Genus AMASTUS Walker.}

\section{AMASTUS EDAPHUS, new species.}

Head and thorax gray-brown, collar with two black points and a point near base of each patagium; abdomen ocher dorsally, gray below; legs gray, fore tibiæ ocher with blue-gray tips. Fore wing gray-brown, mottled, costa and submarginal area lighter; a narrow indistinct light discal mark, Hind wing ocher, cell and below gray, the gray area running out to outer margin, widening to below vein 3. Expanse, $75 \mathrm{~mm}$.

Type.-Male, No. 15220, U.S.N.M., Tehuacan, Mexico, June, 1912 (R. Müller).

\section{EPIMOLIS, new genus.}

Palpi upturned, reaching vertex of head. Fore wing with vein 3 well before the angle of the cell, 4, 5 near the angle, 6 from apex of cell, 7 to 10 stalked, 10 beyond 7,11 from the cell. Hind wing with vein 2 before angle of cell, 3 and 5 stalked, 4 absent, 6,7 coincident, long-stalked with 8 .

Type-species.-Epimolis zatrephica, new species.

EPIMOLIS ZATREPHICA, new species.

Head yellow above, crimson below, the palpi yellow in front; collar yellow; disk purplish, the patagia yellow at base and with a narrow inner crimson edge; abdomen crimson above, white below; fore and mid tibiæ and tarsi yellow with small crimson markings; hind legs white. Fore wing pinkish at basal half with purple tinge, lined with crimson and containing a yellow spot below vein 1 ; costa and apex yellow, the yellow costa excavate mesially, the apical part extending to submedian fold; a large apical curved mark, resting on vein 5, pinkish, shaded with gray, its veins lined with crimson, containing a yellow spot above; several indefinitely placed small gray spots between the discal venules and a subterminal row. Hind wing crimson, apex and outer margin narrowly yellow, the crimson diffused into the yellow. Expanse, $35 \mathrm{~mm}$.

Type.-Female, No. 15221, U.S.N.M., Misantla, Mexico, June, 1912 (R. Müller). 


\section{Family PERICOPID无.}

\section{Genus PERICOPIS Hübner.}

PERICOPIS ZELADON, new species.

Head and thorax dark brown; patagia light yellow on basal third. Abdomen red above with dorsal dark brown stripe; venter light yellow, with lateral brown stripe; legs lined with light yellow. Fore wing dark brown with a broad hyaline V-shaped marking, its apex on tornus, becoming yellow on costa and inclosing a square discal patch; a small projection between veins 4 and 5 . Hind wing reddish orange; a submarginal black band containing irregularly shaped powdery whitish spots; discal venules black marked; an outer short, more or less distinctly developed black line, between veins $2-7$, or shorter; when present the line is bent outward between veins 4 and 5 and may be preceded by semihyaline patches beyond the discal cross vein. Expanse, $63 \mathrm{~mm}$.

Cotypes.-Seven males, No. 14513, U.S.N.M., Orizaba, Mexico, March and May, 1911, August, 1906 (R. Müller); Jalapa, Mexico (Schaus collection).

\section{Family NOCTUIDE.}

Subfamily AGROTINAE.

Genus LYGRANTHOECIA Grote and Robinson.

LYGRANTHOECIA AMBLYS, new species.

Ocherous; thorax olivaceous brown; fore wing olivaceous ocherous; basal and terminal spaces vinous brown, the basal space with a central angle, slightly edged with whitish; a large diffuse dark discal cloud. Hind wing ocherous, shaded with black at base, subcostally and along inner margin; a broad outer black margin; discal mark large, black, semicircular. Expanse, $22 \mathrm{~mm}$.

Cotypes.-Four males, four females, No. 14668, U.S.N.M., Cuernavaca, Mexico, July and August, 1906 (W. Schaus).

The females are a little darker and more contrastingly colored than the males, while the discal mark is square and distinct and of the same vinous brown color as the basal and terminal areas.

\section{Subfamily HADENIN AE.}

\section{Genus MISELIA Hübner.}

MISELIA TRANSVITTA, new species.

Light gray, minutely irrorate; a black basal dash, forked at its apex; inner line whitish, broadly curved, its termination on inner margin close to that of the outer line, which is similar, whitish, both very indistinct; between them and bordering the inner line is a broad oblique black shade, its lower end truncated by the outer line; 
discal marks barely discernible, blackish, annular; subterminal line lost, except for a faint whitish speck above tornus; a small terminal, blackish line, the fringe checkered. Hind wing whitish, the veins fuscous lined, apex and outer margin fuscous; fringe pale. Expanse, $22 \mathrm{~mm}$.

Type.-Female, No. 14445, U.S.N.M., Tehuacan, Mexico, August, 1911 (R. Müller).

\section{MISELIA CALOSCOTINA, new species.}

Fore wing dark lilacine gray, shaded with blackish; subbasal line slender, black, angled, followed by a light area of the ground; inner line surrounded by blackish shadings which spread out below across the median space to outer line and inwardly nearly to base, the line itself black, double, broadly lunulate in four segments; claviform outlined in black, filled with dark shading; orbicular large, oblique, black-outlined, with central core of dark shading; reniform large, joined to the costa by two blackish streaks, black-outlined except without, a concentric line within, shaded with olivaceous and forming a reddish mark toward the outer side; outer line black, double, the outer segment fainter, shallowly wavy below, incurved above cell to costa above reniform; terminal space heavily mottled and shaded with blackish, in which the broadly waved whitish subterminal line is relieved; some reddish shading over the discal venules; a terminal row of black dashes; fringe blackish with white points at the base. Hind wing fuscous shaded, dark, except from cell to inner margin, where it is faintly yellowish, crossed by dark veins. Expanse, 34$36 \mathrm{~mm}$.

Cotypes.-Two males, No. 14542, U.S.N.M., Zacualpan, Mexico, October, 1911 (R. Müller).

\section{Genus HYSSIA Guenée.}

\section{HYSSIA PSEUDOCHROMA, new species.}

Reddish ocherous, faintly mottled with brown, a distinct black patch at end of cell over lower half of reniform; inner line faint, brown, coarsely crenulate, the central arc the most distinct; a brown median shade-line, bent at vein 2 ; outer line crenulate, with a series of long teeth on the veins; subterminal line narrow, yellowish, faint, preceded by a distinct dark shade. Hind wing blackish shaded, the veins black-lined; a small dot on the discal cross-vein. Expanse, $31 \mathrm{~mm}$. Antennæ of male shortly serrate, with bristles and cilia.

Type.-Male, No. 14669, U.S.N.M., Zacualpan, Mexico, November, 1911 (R. Müller).

Genus CIRPHIS Walker.

CIRPHIS STRIGUSCULA, new species.

Rather dark gray; a broad black streak at base below cell; a narrow one below vein 1 above margin from the angle of the wing to 
the middle; a shorter streak at end of cell, bisected by a small white dot at lower angle of cell; all the veins outwardly black-streaked, the streaks edged on both sides more or less conspicuously with light ocherous; a curved outer row of small black dots; a blackish shading inwardly from apex to about vein 5. Hind wing whitish, a little fuscous along veins and margin, with terminal row of black dots. Expanse, $38 \mathrm{~mm}$.

Type.-Male, No. 14670, U.S.N.M., Misantla, Mexico, December, 1911 (R. Müller).

\section{Genus HADENA Schrank.}

HADENA LITHAPHANIA, new species.

Wings long and narrow, the outer margin squarely cut; tornus oblique. Dark gray, a little shaded with blackish; subbasal and inner lines blackish, geminate, slender, obscure; claviform partly outlined in black; orbicular large, elliptical, oblique, pale yellowish, sharply but incompletely edged, with a central dark line; reniform elliptical, of the ground color with a little bronzy tint, black-edged within, with inner crescentic line; outer line blackish, double, crenulate, not contrasted; subterminal line macular, brown, coarsely waved; terminal row of black dashes; fringe pale at base. Hind wing nearly solidly black, the fringe contrastingly pale with central dark line. Expanse, 33-38 mm.

Cotypes.-Male and female, No. 14543, U.S.N.M., Zacualpan, Mexico, October, 1911 (R. Müller).

\section{Genus ERIOPYGA Guenée.}

\section{ERIOPYGA LOLIOPOPA, new species.}

Brown-gray; fore wing with the subbasal half-line slender, whitish, dark-edged within; inner line straight, slightly oblique, whitish, edged with dark brown without; claviform, orbicular and reniform large whitish rings, the claviform without any dark inner edging and consequently less contrasted than the other two stigmata; median shadeline slender, dark brown, running between the discal stigmata, a little bent in the cell; outer line whitish, bent subcostally, edged with dark brown within, the edging broken on the veins, a row of dark-brown dots without; terminal field darker, more densely irrorated with brown than the rest of the wing, crossed by the slender whitish subterminal line, which is well contrasted; a terminal brown band, cut by paler veins into checkered pattern. Hind wing soiled yellowish whitish over the disk, the margin broadly fuscous; veins darker. Expanse, 30-32 mm.

Cotypes.-Two males, No. 14544, U.S.N.M., Zacualpan, Mexico, September, 1909 (R. Müller).

$69077^{\circ}$-Proc.N.M.vol.44-13- 
ERIOPYGA CRACERDOTA, new species.

Dark gray, with slight brown tint; fore wing with the subbasal half-line slender, whitish; inner line straight, slightly oblique, whitish, narrowly and obscurely dark-edged without; claviform absent; orbicular and reniform large whitish rings, the orbicular slightly oblique, the reniform incised without; median shade-line slender, dark, bent in the cell between the stigmata; outer line whitish, sharply bent beyond the cell, followed by a row of square dark-brown dots; subterminal line straight, whitish, distinct; a row of dark marginal dots, cut off by slender pale crescents. Hind wing shaded with fuscous, a little lighter toward base; veins dark. Expanse, 30-31 $\mathrm{mm}$.

Male with long sparse hair on the cell of fore wing beneath; antennæ finely ciliate; side pieces of genitalia rather conspicuously covered with dark yellowish hairs.

Cotypes.-Three males, one female, No. 14545, U.S.N.M., Zacualpan, Mexico, August, 1909; September and October, 1911 (R. Müller).

\section{ERIOPYGA CRENULATA Butler.}

This species occurs in the eastern part of North America to the plains. Hampson ${ }^{1}$ gives also localities in Mexico, Central America, and southward. This southern form is distinct from the northern crenulata, being a larger, heavier species, with coarse and more prominently angled markings. The male anal tuftings are less developed, the pale hairs being absent and they are apparently less extensible. On the under side of the fore wing of the male the down-curved hairs extend below the cell and are not confined to the area in and beyond it, as Hampson correctly figures for crenulata (fig. 74). The typical form of this southern species occurs in Mexico, Central America, Venezuela, and Ecuador. To the southward smaller, less strongly marked forms occur; whether species or races can not well be decided from the present material. They are separately described below.

ERIOPYGA VESQUESA, new species.

Large, robust, the male with the down-curved hairs on fore wing below extending below the cell. Purplish brown, the lines pale, fine; subbasal half-line slightly curved; inner line oblique, dislocated in cell, preceded by black dots on vein 1; orbicular and reniform both large, oblique, pale-outlined; outer line roundedly angled at right angles on upper third, followed by a row of indistinct double black dots; subterminal lines erect, nearly straight, the terminal space appearing a little paler, with distinct crenulate pale marginal line. Hind wing dark brown, the veins darker, fringes pale. Expanse, $35-40 \mathrm{~mm}$. 
Cotypes.-Two males, two females, No. 15222, U.S.N.M., Loja, Ecuador, 1890 (P. Dognin); Aroa, Venezuela (Schaus collection); Cordoba, Mexico, May, 1906 (W. Schaus).

\section{ERIOPYGA OACHE, new species.}

Smaller than the preceding, grayer, less intensely colored, the bend in the outer line making a less acute angle, but all the markings the same as in vesquesa. Expanse, $30 \mathrm{~mm}$.

Cotypes.-One male, one female, No. 15223, U.S.N.M., Peru (Schaus collection).

\section{ERIOPYGA ULTIMELLA, new species.}

Small, shining light gray-brown, the markings little relieved and difficult to trace, all essentially as in the preceding form, but here the crenulate marginal line seems wholly lost. The hind wings are a light, duller brown, and, especially in the male, show a whitish suffusion over the disk. Expanse, 28-34 mm.

Cotypes.-One male, two females, No. 15224, U.S.N.M., Rio de Janeiro and Castro, Parana, Brazil (Schaus collection).

\section{ERIOPYGA LANARIS Butler.}

This species has much the same markings as the preceding forms, the outer line being less prominently angled. The male is easily recognized by the rough scaling on the wings below, which involves the hind wings. Females are less easy to determine, and certain small specimens before me were named lanaris by authority. However, I now possess a male with very different secondary sexual characters, agreeing in size and markings with the females. It is described below as E. enages. I have also from Peru a single male, closely resembling lanaris above, but without rough scaling on the hind wings. It may be described as

\section{ERIOPYGA DOLIA, new species.}

Large, robust, the tegulæ with black tips; reddish brown, the lines pale, slender; basal half-line curved; inner line sharply angled on subcosta and submedian; a rusty brown costal shade beyond to submarginal line; orbicular and reniform large, oblique, pale ringed; mesial shade line oblique, dark; outer line obtusely angled subcostally, followed by two rows of black dots; submarginal line erect, faint. Hind wing gray-brown with dark veins and pale fringe. Male with rough scales over the whole of the fore wing below, except the margins, but none on the hind wing. Expanse, $37 \mathrm{~mm}$.

Type.-Male, No. 15225, U.S.N.M., Peru (Schaus collection).

ERIOPYGA ENAGES, new species.

Markings as in E. crenulata Butler (North American), the male secondary sexual characters as in E. cynica Guenée. Grayish brown, 
the lines pale, faint. Orbicular rather small, oblique; reniform very little constricted; outer line bent very nearly at right angles; no marginal crenulate markings. Expanse, $29 \mathrm{~mm}$.

Type.-Male, No. 15226, U.S.N.M., Misantla, Mexico, March, 1912 (R. Müller).

The females, above referred to, are redder than the male type, the orbicular is larger and more distinctly oblique, the reniform is well constricted and the outer line is not bent at a right angle. On account of these differences they have not been made cotypes, although I think it probable that the differences are varietal only.

Eight females, Orizaba, Mexico, February, 1911, April and May, 1910, October, 1908, November, 1910 (2), December, 1911 (R. Müller); Coatepec, Mexico (Schaus collection).

\section{Subfamily CUCULLIIN AE.}

Genus MOMAPHANA Grote.

MOMAPHANA SYLVIA, new species.

Thorax green, the patagia and tegulæ tipped with white; a white band behind the middle. Abdomen shaded with green, the tuft on the basal segment dark-tipped. Fore wing with the ground white, largely overlaid with rich grass-green; a small black mark on costa close to base, edged with white; lines converging below and uniting at vein 1 , the median space filled with black below up to or in the cell between the stigmata, the lines themselves forming part of this black and brown mesial wedge, which is truncated below at vein 1 , notched within on median vein and coarsely scalloped without; orbicular very large, green, more or less completely white-ringed; reniform large, variously constricted, white, with green shades encroaching on it above and below; the median triangle is broadly edged with white within, narrowly so without; terminal field green, the subterminal line white narrow, broken, with a black mark on costa, a broad adjoining white shade below, then a black wavy inner border, sagittately produced on vein 2 and with a brown streak outward to tornus; fringe white and green, with black tips to the green segments; costa spotted black and white. Hind wing white, silky, semihyaline, a little shaded with green around apex. Expanse, 40-44 mm.

Cotypes.-Seven males, five females, No. 14514, U.S.N.M., Southern Arizona (J. Doll); Tehuacan, Mexico, June and October, 1911 (R. Müller); Guadalajara, Mexico (Schaus collection); Zacualpan, Mexico, September, 1911 (R. Müller); Cuernavaca, Mexico, June, July, August, 1906 (W. Schaus), November, 1911 (R. Müller).

The species is allied to Momaphana britlians Barnes from Arizona, though obviously distinct. 
MOMAPHANA ANNADORA, new species.

Fore wing nearly entirely overlaid with green, presumably of a grass-green, but faded to yellowish in the specimen by wetting in the relaxing-jar. The markings are of the pattern of the preceding species, but the median black space is very wide, showing a broad area beyond the reniform, broad below and broadly truncate on vein 1 ; no white edging within, a very narrow one without; orbicular small, green; reniform large, square, constricted, green with a small white crescent in the center and narrow white edge below; space beyond solidly green except for the white subterminal line, which has no accompanying white shades but only a black costal mark and a three-pronged black triangle below; the streak from this to tornus is black-brown, short and thick; costa narrowly black and white spotted. Hind wing white, silky, semihyaline. Expanse, $36 \mathrm{~mm}$.

Type.-Female, No. 14515, U.S.N.M., Tehuacan, Mexico, August, 1911 (R. Müller).

\section{Subfamily SARROTHRIPIN AE.}

Genus BAILEYA Grote.

BAILEYA RESTITANS, new species.

Gray, washed with whitish through the center of the wing; basal area, broad on inner margin, dark ocher with a white outer edge and a black costal bar; inner line lost; stigmata lost, the reniform showing a little as a spot in an irregular dark mesial line; a brown-black triangular costo-apical marking cut vertically by white, the outer section nearly trisected longitudinally by white; from this the slender irregularly wavy black outer line, followed by white and near inner margin by a short roundedly dentate black line; terminal veins slightly dark-lined. Hind wing fuscous, a little lighter on the disk, the veins finely black-lined. Expanse, $29 \mathrm{~mm}$.

Type.-Female, No. 14546, U.S.N.M., Orizaba, Mexico, July, 1908 (R. Müller).

This species has the size of $B$. ophthalmica Guenée, but the markings are as in B. australis Grote.

\section{Subfamily ACRONYCTIN AE. \\ Genus BAGISARA Walker.}

BAGISARA OULA, new species.

Thorax and fore wing shining whitish gray, without yellow tint, shading to brown at outer margin, the fringe the darkest; three fine slender lines, the inner one far out, bent at right angles subcostally; middle line more strongly bent, running into a point at vein 6 ; outer line bluntly bent, curved only. Hind wing creamy whitish with pale brown shading outwardly. Abdomen like the hind wing, with dorsal brown shading. Expanse, $33 \mathrm{~mm}$.

Cotypes.-Three females, No. 14428, U.S.N.M., Jalapa, Mexico (Schaus collection). 
BAGISARA DEMURA, new species.

Ocher yellow, the fore wing with a faint brownish tint, smooth, silky, not irrorate; fringe brown; lines slender, brown, not waved; inner line bent and an obtuse angle on subcosta; outer line bent at right angles on vein 7 ; subterminal line similarly bent but less sharply. Expanse, $30 \mathrm{~mm}$.

Cotypes.-Male and female, No. 14442, U.S.N.M., Guadalajara, Mexico (Schaus collection); Misantla, Mexico, August, 1911 (R. Müller).

BAGISARA XAN, new species.

Ocher yellow, the fore wing with a faint brownish tint, smooth, silky, with sparse brown irrorations; fringe dark brown, the color spreading inward centrally across the subterminal line; lines slender, brown, not waved; inner line curved on subcostal; slight trace of an annular reniform; outer line bent at an acute angle on vein 7 ; subterminal line similarly bent at right angles, the lower segment arcuate. Expanse, $39 \mathrm{~mm}$.

Type.-Female, No. 14443, U.S.N.M., Orizaba, Mexico (Schaus collection).

\section{Genus PERIGEA Guenée.}

PERIGEA SUTRIX, new species.

Gray, with ochraceous tint, smooth, lustrous, silky; markings black, all broken and powdery, more or less obsolete; inner line single with a strong indentation at vein 1 ; a black shading at the point of the claviform; a more extensive shading between the discal stigmata and surrounding the lower part of the reniform; the stigmata are themselves principally outlined by this shade, ocherous, with powdery dark centers, the orbicular elliptical, a little oblique the reniform large, emarginate without; outer line a double series of points, the two rows well separated; subterminal line edged within by a black shade more or less distinctly, in one specimen strongly so. Hind wings creamy white in the male, fuscous in the female, the fringes pale. Expanse, $32 \mathrm{~mm}$.

Cotypes.-Two males, two females, No. 14671, U.S.N.M., Misantla, Mexico, January, 1909, June and August, 1910 (R. Müller); Oaxaca, Mexico (Schaus collection).

Very near $P$. sutor Guenée, but differing in detail, the hind wings of the male especially being much paler.

PERIGEA PYROMPHALUS, new species.

Rosy gray, with more or less orange shading over center of wing; lines double, dark, indistinct, crenulate, the outer forming a series of minute points beyond; orbicular small, round, orange tinted, with 
brown border and concentric ring; reniform narrow, containing bright orange center, a white point at its lower edge continued into a fine line and a point at the upper edge; a brown central crescent; a blackish shade follows the reniform up to the outer line; subterminal line black, waved, broken into a series of spots, of which the lower one is large and rounded. Hind wing blackish fuscous, the fringe pale. Expanse, $28 \mathrm{~mm}$.

Cotypes.-Two males, No. 14672, U.S.N.M., Misantla, Mexico, April and November, 1911 (R. Müller).

\section{Genus MICRATHETIS Hampson.}

MICRATHETIS DASARADA Druce.

This small, narrow-winged species shows a tendency to local forms in its wide distribution. The Mexican form shows in general a light straw-colored ground, without marked olive-brown shades, the outer spot at the end of the cell large and round. Costa Rican examples before me show marked olive-brown shading within the oblique outer line, especially in females, while the discal dot is minute or absent. In Brazilian females this tendency is more pronounced, the purplish shading being more uniform over the wing, the discal mark nearly invisible. Specimens from the Guianas are smaller, the dark shading forming a band through the center of the wing, leaving the cell and terminal areas pale straw-color. The outer band is less oblique than in dasarada. For this form the varietal name dacula may be suggested. Cotypes of the form dacula, No. 14673, U.S.N.M., five males, eight females, St. Jean, Maroni River, French Guiana; 60 miles up the Maroni River (one female); Demerara, British Guiana (one female), all from Mr. Schaus's collection.

\section{Genus MENOPSIMUS Dyar.}

\section{MENOPSIMUS CADUCUS Dyar.}

Menopsimus caducus Dyar, Journ. N. Y. Ent. Soc., vol. 15, 1907, p. 110.

Thalpochares fractilinea Sмгтн, Ann. N. Y. Acad. Sci., vol. 18, 1908, p. 125.

This species is not known to extend its range to Mexico, but is mentioned in this connection on account of its very similar facies to the preceding species and to the following new genus. I described Menopsimus as a deltoid genus, but according to Sir G. F. Hampson's tables it falls in the Acronyctinæ. The venation is as follows: Fore wing with veins 2 and 3 before the angle of the cell, 5 well above the angle, 6 below the upper angle, 7 curved to costa, 8 and 9 stalked, 10 absent, 11 from the cell, no accessory cell; hind wing with vein 2 well before the angle of the cell, 3 and 4 stalked, 5 very weak, from the middle of the discocellulars to an excavation in the outer margin, 6 and 7 stalked, 8 joined to the cell for nearly the basal half. 
The genus falls in Hampson's table ${ }^{1}$ with Nolasodes Hampson, and with the following, the three being easily separated by the structure of the palpi.

\section{HYPENOPSIS, nevv genus.}

Fore wing with veins 2,3 , and 4 well separated, 5 arising shortly above the angle of the cell, 6 below the upper angle, 7 running to the outer margin, 8, 9, and 10 stalked, all running to the costa, no accessory cell, vein 11 from the discal cell; hind wing with vein 2 long before the angle of the cell, 3 and 4 stalked, 5 very weak, from the middle of the discocellulars to an excavation in the outer margin, 6 and 7 stalked, 8 free from the cell to base. Palpi with the second joint a long thick blade, twice as long as the head, porrect, the third joint long, very slender and standing upright.

Type-species.-The following species:

\section{HYPENOPSIS MACULA Druce.}

Hypenodes macula Druoe, Biol. Cent.-Am., Lep. Het., vol. 1, 1891, p. 441, pl. 36, fig. 1.

Described from two specimens from Chiriqui, Panæma. I have before me thirteen from Jalapa and Orizaba, Mexico, one from São Paulo, S. E. Brazil, one from Castro, Parana, Brazil, all from Mr. Schaus's collection, and four from La Puerta Valley, near San Diego, California, from Mr. G. H. Field.

\section{Genus HYDROECIA Duponchel.}

HYDROECIA ARNYMAI, new species.

Rufous yellowish, marked with red-brown; base of fore wing dark, the subbasal line broad, pale; inner line of three brown arcs, outwardly oblique; claviform a half of a brown ringlet in a pale area; orbicular round, pale, its border blending with the dark ground surrounding; a dark shade-band across middle of wing, angled on median vein, darker than the general ground color; reniform pale with faint dark concentric center; outer line single, crenulate, excurved over cell, terminating the brown-irrorate median area; a rounded brown patch on costa ; subterminal line of three long shallow arcs, the terminal space solidly brown; fringe dark. Hind wing reddish brown, the veins a little darker, discal area somewhat yellowish between the veins. Expanse, $26 \mathrm{~mm}$.

Type--Male, No. 14674, U.S.N.M., Zacualpan, Mexico, December, 1911 (R. Müller). 


\section{Genus NOCLOA Smith. \\ NOCLOA PERIODITA, new species.}

Thorax purple-gray; vertex of head yellow. Fore wing nearly entirely suffused with purple-gray; two light yellow lunules below the median vein, representing undulations of the obsolete inner line; orbicular and reniform large, but showing faintly by their slightly lighter, yellowish inner borders; outer line even, dentate on the veins, relieved only by the broad following yellow area, irrorated with red, which is cut by purple on the veins and succeeded by the purple-gray margin. Hind wing purplish fuscous, a little lighter along the veins, showing faintly a dark discal spot and outer mesial line. Expanse, $30 \mathrm{~mm}$.

Type--Female, No. 14440, U.S.N.M., Tehuacan, Mexico, August, 1911 (R. Muller).

\section{Genus CHALCOPASTA Hampson.}

CHALCOPASTA CHALCOCRASPEDON, new species.

Thorax purple-brown; vertex and collar ocherous. Fore wing purple-brown, the basal and terminal spaces solidly metallic bronzy; extreme base purple; beyond it to inner line bronze; inner line bent at right angles in the middle, dark, single, not contrasted; orbicular large, bronze filled; reniform lost, only a slight bronzy discoloration; outer line outwardly oblique from costa, bent at an acute angle, then nearly straight to middle of inner margin, the space beyond to fringe solidly bronze, except the costal triangle; fringe purple. Hind wing pale fuscous with a broad lighter band beyond the middle. Expanse, $30 \mathrm{~mm}$.

Type.-Female, No. 14441, U.S.N.M., Zacualpan, Mexico, September, 1911 (R. Müller).

Subfamily HRA.STRIIN AE.

Genus TARACHIDIA Hampson.

TARACHIDIA HEONYX, new species.

Pure white; outer half of fore wing brown, the line dividing the colors straight, starting near middle of inner margin, running a little obliquely outward almost to costa, then bent at nearly right angles obliquely outward, and again angled and reaching costa just before apex. Abdomen and hind wing yellowish white, the wing faintly fuscous tinted on the margin; fringe pale. Expanse, $20 \mathrm{~mm}$.

Type.-Female, No. 14438, U.S.N.M., Cerritos, San Luis Potosi, Mexico, August, 1911 (R. Müller). 


\section{Genus EUSTROTIA Hübner.}

EUSTROTIA MOCHENSIS Schaus.

Photedes mochensis Schaus, Trans. Amer. Ent. Soc., vol. 30, 1904, p. 157.

Micromonodes mochensis Hampson, Cat. Lep. Phal. Brit. Mus., vol. 8, 1909, p. 565. Monodes cassida Dyar, Proc. U. S. Nat. Mus., vol. 43, 1912, p. 64.

Having found a number of specimens of this species in the Schaus collection, and having recently received others from Mr. Müller, I have been able to examine carefully the venation. There are two important errors in Hampson's figure, namely, that vein 5 of the hind wing is really strong and distinct, not weak, as there shown, and there is a small accessory cell present on the fore wing, joining vein 10 to the stalk of veins 7 to 9 . The correction of these matters will place the species in the Erastriinæ and in the genus Eustrotia. The species is not very similar to the other species of Eustrotia, but I do not detect any characters for generic separation. It will fall in the section with E. chuza Druce by the long third joint of the palpi.

\section{EUSTROTIA PULMONA, new species.}

Photedes pulmona Schaus, MS.

Dark reddish gray; fore wing with distinct black mesial band, angled a little centrally; a black dot in the cell and lunule at end of cell; lines slender, black, the inner angled outwardly in the middle, the outer angularly excurved, neither conspicuous, the outer with little light specks along its course; a row of many black strigæ along the costa; a fine crenulate terminal black line, with light specks in the excavations. Hind wing blackish to nearly black, with an outer mesial lighter line and a faint inner darker one, the fringe reddish, with terminal line as on fore wing. Expanse, $27 \mathrm{~mm}$.

Cotypes.-Male and female, No. 14675, U.S.N.M., selected from a series, Jalapa, Mexico (Schaus collection).

The palpi have the third joint long as in E. mochensis Schaus, to which the present species is allied.

\section{Genus DIASTEMA Guenée.}

\section{DIASTEMA PANTELES, new species.}

Gray, with a very slight rosy tint; base light, but a blackish shading on the costal half of the extra-basal space; inner line dark, arcuate, confused by the stigmata, the claviform and orbicular forming pale ellipses beyond it and small pale segments within; these marks project into a deep black shade that runs from the costa a little obliquely and stops at the claviform; reniform large, elliptical, a narrow black ring filled by the ground color with an inner brownish concentric line, the black rim fused to the median shade; outer line blackish, crenulate, fine and faint; subterminal line twice angled above and edged 
within by a deep black shade, incurved below at submedian and without the black shade; three black streaks above across the terminal space; a row of black terminal dashes in a light line. Hind wing brownish gray, streaked with blackish on the veins on the lower half; a terminal fuscous line. Expanse, $30 \mathrm{~mm}$.

Type.-Female, No. 14439, U.S.N.M., Tehuacan, Mexico, September, 1911 (R. Müller).

\section{Subfamily EUTELIIN AE.}

\section{Genus EUTELIA Hübner.}

EUTELIA AMATRIX, new species.

Light reddish, area between veins 1 and 2 and at apex slaty gray; a brown half-band at basal third of inner margin, edged by a whitish line, which shows most distinctly in an arc between veins 1 and 2, limiting the gray area; a reversed white arc beyond, the gray shade running upward submarginally; terminal area narrowly red-brown below, widening above the bend in outer margin, limited by a white are which joins an oblique line running to costa; gray apex cut off by a whitish line; discal mark pale, lunate, clouded. Hind wing white; a broad outer black band, shading to red on the margin. Expanse, $32 \mathrm{~mm}$.

Type.-Female, No. 15227, U.S.N.M., Iguala, Guerrero, Mexico, June, 1906 (W. Schaus).

\section{Subfamily CATOCALIN AE.}

\section{Genus CELIPTERA Guenée.}

CELIPTERA SURRUFULA, new species.

Fore wing soft gray, slightly violaceous in tone; inner line shaded black, coarsely angulated, upright; discal mark narrow, curved; outer line crenulate, with whitish specks in the undulations, shaded, a large cloud opposite the cell and one on submedian; the line is marked on costa, then slender, excurved over cell; subterminal line a row of black dots; a terminal row of short dashes. Hind wing reddish gray, with terminal short black dashes. Expanse, $36 \mathrm{~mm}$.

Type.-Male, No. 14498, U.S.N.M., Cerritos, San Luis Potosi, Mexico, August, 1911 (R. Müller).

\section{Genus ZALE Hübner.}

ZALE RHIGODORA, new species.

Dark brown, smooth and uniform, without contrasts; basal space of fore wing darkly mottled, obscurely strigose with black, its outer edge sharply and roundedly limited from inner third of costa to near base of inner margin; no limiting line, but a slight following light purplish shade; costa with narrow pale streaks; reniform scarcely 
darker than the ground, moderate, narrowly white-edged without; outer line black, slender, tremulous, obscure, excurved centrally, with a small black spot within above vein 4, narrowly white-marked on costa; subterminal line distinct, outcurved in the middle, forming two inward arcs, limiting the dark median space, but scarcely itself a line; black shadings from the projection to the outer margin, completing the lower arc and cutting off a lunate space around tornus, which is purplish shaded and marked with a small white spot in the submedian space; margin crenulate. Hind wing colored like the fore wing, with many fine wavy transverse blackish lines; submarginal line curved, cutting off a broad lunate space on the margin, itself brown, double, the marginal space lightened with purplish. In the female the light purplish shades are absent, their places being taken by blackish shades bordering the lunate areas. Expanse, $45 \mathrm{~mm}$.

Cotypes.-Three males, three females, No. 14516, U.S.N.M., Misantla, Mexico, January and September, 1911 (R. Müller).

\section{Subfamily NOCTUINAE.}

\section{Genus CAMPOMETRA Guenée.}

\section{CAMPOMETRA DISTILLA, new species.}

Thorax dark, blackish, the disk intermixed with white scales, the collar brownish in front. Fore wing with the ground color gray, with a slight olivaceous tint, overspread with blackish shades; base darkly shaded, the subbasal line black, fine, dentate, relieved by narrow lighter shades; inner line similar, the ground color appearing on both sides of it; orbicular a black dot; mesial line black, irregular, shaded toward base and with an outward duplication, which is distinctly present on the right wing of the specimen and not on the other; reniform marked by a white speck on each of the four corners, the two outer ones joined by a white lunule; a blackish rounded patch on costa above, marked with white before and behind, the outer followed by blackish and another white streak; other line slender, black, dentate, followed by a bluish-black dentate shade; a light shade of the ground color through middle of wing; subterminal line dentate, black, with an outward shaded duplication; a row of black dashes close to the margin preceded by white specks; a terminal wavy black line followed by white specks at the base of the fringe. Hind wing blackish, solidly black on costal third with a bronzy luster; several series of black and gray specks over the disk; a black dentate subterminal line with outward duplication, not crossing costal third; terminal markings as on fore wing. Expanse, $48 \mathrm{~mm}$.

Type.-Female, No. 14436, U.S.N.M., Misantla, Mexico, August, 1911 (R. Müller). 
Genus MATIGRAMMA Grote.

MATIGRAMMA PSEGMAPTERYX, new species.

Soft bluish gray, dark in tone; lines blackish, wavy, not contrasted, forming about ten dark specks along the costa; inner and median lines slender, waved; a dot toward base of cell; reniform a large, kidney-shaped pale area; outer line a little more distinct than the others, edging the pale reniform, broken below but joined by a line from costa within reniform; three wavy lines between reniform and margin, the inner one shaded and forming an enlargement below vein 2; a waved terminal dark line; fringe crossed by light streaks. Hind wing of the same color as fore wing, crossed by seven indistinct waved dark lines, the subterminal one a little the most distinct and well scalloped; fringe as on fore wing. Expanse, $32 \mathrm{~mm}$.

Type.-Female, No. 14437, U.S.N.M., Cerritos, San Luis Potosi, Mexico, August, 1911 (R. Müller).

\section{Genus PROTHYMIA Hübner.}

PROTHYMIA CATAPLEXIS, new species.

Yellow; vertex, sides of front and bases of patagia crimson. Fore wing yellow; costa crimson on basal half, the crimson band notched beneath; outer half of wing crimsom, the inner border oblique and a little irregular, the crimson area inclosing a yellow triangular area on inner margin. Hind wing fuscous tinged. Beneath, fore wing dark gray, crimson tinged toward apex. Hind wing whitish. Expanse, $19 \mathrm{~mm}$.

Type.-Female, No. 14517, U.S.N.M., Sierra de Guerrero, Mexico, October, 1911 (R. Müller).

\section{Genus PLEONECTYPTERA Grote.}

PLEONECTYPTERA IGNILINEA, new species.

Fore wing dark violeceous gray, the two lines nearly straight, parallel, dark, shaded with coppery red, the outer with a following pale border in which the red tint prevails; reniform outlined in dark faintly; subterminal space darker, purplish, irregularly limited outwardly by the paler marginal area; narrow dark terminal dashes. Hind wing lighter than fore wing, but of the same general tone; traces of a mesial darker line. Expanse, $25 \mathrm{~mm}$.

Type.-Female, No. 14547, U.S.N.M., Tehuacan, Mexico, August, 1910 (R. Müller).

Genus PANGRAPTA Hübner.

The foliowing species are placed provisionally in this genus. The specimens are all females. 
PANGRAPTA ALOPOPIS, new species.

Dark lilacine brown; reniform elliptical, with a white crescent on the inner border, a minute white dot at upper and lower edges, a darkred stain and white specks in the center; inner line coarsely dentate, broken, blackish, followed by the black punctiform orbicular; outer line white at its inception on costa, then blackish, dentate, outcurved over cell; a following dusky shade above; subterminal line faint, dark, clouded with blackish on costal fourth; a row of minute terminal black dots. Hind wing of the same color as fore wing and similar pattern; a large rust-red discal stain; mesial line blackish, dentate; subterminal line whitish, obscure; terminal dots as on fore wing. Expanse, $23 \mathrm{~mm}$.

Type.-Female, No. 14495, U.S.N.M., Misantla, Mexico, August, 1911 (R. Müller).

PANGRAPTA HERBITECTA, new species.

Fore wing with a rounded projection at the middle of the outer margin; lilacine gray; two black specks near base for subbasal line; inner line coarsely wavy, pale, brokenly edged with black; orbicular round, small, green; median shade with a brown-black triangle on costa, thence continued faintly across wing; reniform brown-filled, stained with green; outer line whitish, narrow, distinct, not waved, excurved over cell, relieved on a dark ground; a large brown-black costo-subapical triangular patch with green below, between it and the subterminal line; subterminal line obscure, pale; a row of minute terminal dots; a larger spot below the marginal angle. Hind wing with a small point on the middle of the margin; gray, like the fore wing; a large green stain on the middle of the inner margin between the faint mesial and outer lines. Expanse, 19-21 mm.

Cotypés.-Two females, No. 14496, U.S.N.M., Misantla, Mexico, September, 1911 (R. Müller); Orizaba, Mexico (Schaus collection).

\section{Genus GLYMPIS Walker.}

\section{GLYMPIS PHOENICIMON, new species.}

Rufous-brown; fore wing with two straight light ocherous lines; a small spot in cell and one at end darker brown; a subterminal row of brown specks situated in a light line, which in some specimens is more distinct than the specks; area between the outer line and subterminal specks sometimes darker than the rest of the wing. Hind wing of the male slightly tinged with rufous outwardly, the long pencil in a fold along anal margin black. In the female the hind wing is strongly tinged with bright rufous outwardly. Expanse, $25-27 \mathrm{~mm}$.

Cotypes.-No. 14676, U.S.N.M., male, Cuernavaca, Mexico (Schaus collection); female, Zacualpan, Mexico, December, 1911 (R. Müller); two females, Cuernavaca, Mexico (Schaus collection). 


\section{Family NOTODONTIDÆ.}

\section{Genus DASYLOPHIA Packard.}

\section{DASYLOPHIA RUFITINCTA, new species.}

Male.-Thorax reddish brown; collar clayey yellow. Fore wing bright reddish brown, the color extending below vein 2 to the tornus, but a little lighter at base and defined by a faint curved dark line near middle of wing; this line seems to be incised at median vein and to run obliquely across median space to near base of wing, but is very faintly relieved; apex broadly blackish shaded, the veins black-lined, with dark gray streaks between them, separated from the veins by pale ocherous lines; a series of oblique black streaks on the margin, the two between veins 2 to 4 , more distinct, more inwardly placed, and with ocherous crescents. Hind wing soiled white, the veins touched with gray outwardly and a gray shade at anal angle. Expanse, $40 \mathrm{~mm}$.

Female.-Ground color of wing more ocherous, with less red tint than in the male; basal area ocherous, rounded without, incised on median vein and powdered with dark scales, especially toward the base; outer area shaded with dark brown, the cloudings forming two ill-defined oblique bands, the apex wholly dark; veins black-lined beyond the cell; terminal markings faint, only the pale crescents between veins 2 to 4 showing. Hind wing soiled white, a terminal brown line, the fringe a little brown shaded. Expanse, 46-51 mm.

Cotypes.-Two males, two females, No. 14466, U.S.N.M., Orizaba, Mexico, September, 1911 (R. Müller); Cordoba, Mexico, December 26-28, 1907 (F. Knab); May,1906 (W. Schaus).

The species has the wings unusually long and narrow; the hairwhorls at the bases of the antennæ are short and do not become confluent to form the high vertical tuft characteristic of the genus.

The specimens show some individual diversity. The male from Orizaba is described above. The male from Cordoba is much less distinctly marked. Its color is the same, but the dark apical shading is much less noticeable. Of the females, the one collected by Mr. Knab I consider typical. The other is a little larger and darker, with the shadings heavy and extensive, crossing the basal light space and almost wholly obscuring the submarginal lunate marks.

CALOMATHETES, new genus.

Fore wing with a tuft of scales on inner margin and one before anal angle; outer margin crenulate; no areole; veins 8-10 stalked; antennæ of male lengthily bipectinated to the tip.

Type-species.-The following species:

IALOMATHETES HALMAPHYLLA, new species.

Fore wing yellowish brown, broadly shaded with purplish beyond the outer line; a few black specks and streaks near the base; inner 
line composed of a series of elongate black dots in three irregular rows. curving across the wing, forming a slender line above the tooth on inner margin; the basal space has a slight purplish washing; mesial space lighter, especially just before the outer line, a little diversified with brownish lines, a trace of reniform mark and a black streak on discal fold; outer line double, composed of two series of black crescents alternating with whitish ones, obliquely from before the outer tooth on inner margin to costa before apex; traces of a subterminal line in the purplish marginal shading, which expires at apex; veins dark-lined at the margin; a row of purple-white spots in the projections of the fringe. Hind wing fuscous shaded, the veins darker, the fringe contrastingly pale. Expanse, $42 \mathrm{~mm}$.

Type.-One male, No. 14465, U.S.N.M., Tehuacan, Mexico, September, 1911 (R. Müller).

\section{Genus PSILOCRON Felder.}

PSILOCRON APHRETHESA, new species.

Thorax gray, intermixed with olive; abdomen blackish dorsally, except the last segment, which is pale gray. Fore wing pale gray, almost whitish at base and along basal half of costa, shaded with olive toward apex (faded to brownish in the specimen); base narrowly olive gray; lines olive gray, double, the inner broken and obsolescent across cell, distinct below, with a strong inward projection on submedian fold; a small olive mark in center of cell and a larger one at the end, both lunate; outer line faint costally, geminate, crenulate, slightly excurved over cell, followed by a row of olive-gray spots; subterminal line whitish, irregular, not contrasted; veins terminally dark-lined. Hind wing grayish, the disk translucent, costa whitish with two gray bars; termen blackish, fringe whitish, inner margin broadly shaded with blackish except at tornus. Expanse, $50 \mathrm{~mm}$.

Type.-Male, No. 15228, U.S.N.M., Misantla, Vera.Cruz, Mexico, March, 1912 (R. Müller).

The species looks like a Heterocampa, allied to H. atrax Schaus and H. dolorosa Schaus.

\section{'Genus FARIGIA Schaus.}

\section{FARIGIA MALOMEN, new species.}

Female.-Ground color light gray with a carneous tint, powdered with blackish and marked with powderings and patches of metallic green; ordinary lines blackish, geminate, obscured by shadings; a subterminal row of partly confluent black dashes; a broken black bar along submedian fold from base to outer line; a black shading occupying the inner half of median space, covering and partly obscuring the inner line; discal mark narrow, black-outlined; a narrow deep black shade covering and filling the outer line. Hind wing brown, not quite uniformly colored. Expanse, 50-52 mm. 
Cotypes.-Two females, No. 15229, U.S.N.M., Cordoba, Mexico, May, 1906 (W. Schaus); Misantla, Mexico, May, 1912 (R. Müller).

The following table will separate the five species of Farigia known to occur in Mexico:

Sexes dimorphic; antennæ of female bipectinate; male with raised whitish discal mark.............................................montana Druce.

Sexes monomorphic; antennæ of female simple; male with discal mark, if present, dark.

A black shade from base of fore wing below cell bordering the subterminal line, hydriana Schaus.

Black shade over median space in lower half of cell to inner margin, not crossing outer line ....................................magniplaga Schaus.

No broad black shades.

Outer line, inner half of median space and submedian streak narrowly black shaded ......................................malomen Dyar.

No black linings except the ordinary markings.............vecina Schaus.

It seems possible that the four forms hydriana, magniplaga, malomen, and vecina may prove to belong to one variable species since they differ only in the black shadings and not in pattern.

\section{Family GEOMETRID压. \\ Genus OENOTRUS Druce.}

OENOTRUS MELANODORA, new species.

Black; collar, patagia, orbits, palpi and fore coxæ, orange; wings black, the tip of fore wing white and on fringe at apex. Beneath as above, the apex of fore wing and the hind wing leaden black, with the veins deep black. Expanse, $28 \mathrm{~mm}$.

Type.-One male, No.14301, U.S.N.M., Sierra de Guerrero, Mexico, June, 1910 (R. Müller).

\section{OENOTRUS BIPENNIS, new species.}

Black; vertex and disk of thorax orange yellow; a large patch of this color on fore coxa; wings black, the extreme base of forewing orange red, the color extending out farther on costa and inner margin. The forewing is more brownish black than the hind wing; beneath both wings bluish black. Expanse, $34 \mathrm{~mm}$.

Type.-One male, No. 14302, U.S.N.M., Sierra de Guerrero, Mexico, June, 1910 (R. Müller).

The forewings are longer and more drawn out than usual.

\section{Genus HYDRIOMENE Hübner.}

HYDRIOMENE POTOSIATA, new species.

Palpi short, upturned, reaching the middle of the front. Forewing fuscous, a little washed with whitish from the cell to before apex; an irregular black line from the origin of vein 2, continued by a black 
shade to apex; a black mark beyond middle of inner margin; indications of transverse lines across the wing, apparently numerous and double but scarcely legible; veins black-lined close to the margin. Hind wing uniform brownish fuscous. Expanse, $24 \mathrm{~mm}$.

Type.-One female, No. 14459, U.S.N.M., Cerritos, San Luis Potosi, Mexico, August, 1911 (R. Müller).

\section{HYDRIOMENE GRETTARIA, new species.}

Forewing rather pointed at apex, dark gray, the markings indistinct; lines slender, blackish, coarsely waved, about five traceable, one forming an arc at end of cell distinct, black; ground color alternately lighter and darker between the lines, the broadest light areas at base and through middle of wing. Hind wings light gray, uniform. Expanse, $26 \mathrm{~mm}$.

Type.-Male, No. 14677, U.S.N.M., Zacualpan, Mexico, December, 1911 (R. Müller).

\section{Genus CATOCLOTHIS Hulst.}

\section{CATOCLOTHIS GYMNOPOMPARIA, new species.}

Fore wing with the costal half dark gray, crossed by four broad bands of paler gray of equal width with the dark portions; ordinary lines lost; rather numerous short black streaks centrally, the median vein narrowly lined with black scales; the light bands are sometimes rufous tinted, the rufous in the cell occasionally crossing the middle band and forming a long rufous area; inner half of wing and all of hind wing smooth silky light gray without markings. There is a little black scaling along inner margin of fore wings. Body parts dark gray. Expanse, $35 \mathrm{~mm}$.

Cotypes.-Five males, four females, No. 14518, U.S.N.M., Popocatepetl Park, Mexico, 8,000 feet, June, 1906 (W. Schaus).

\section{Genus CAMBOGIA Guenée.}

CAMBOGIA AGROICA, new species.

Ground color light greenish yellow, marked with purplish rosecolored bands; a broad stripe along costa, salmon tinted on costal edge, widened to outer band, then abruptly narrowed; inner band curved, the edges dark purplish; outer band similar, its outer edge crenulate; submarginal band narrower and more uniform; a short slender line across apex. Hind wing with a band close to base; a wide median space of the ground color; outer and submarginal bands joined at costa, then narrowly separated, each broad and with darker purplish edges. Outer margin angled in the middle. Expanse, $20 \mathrm{~mm}$. 
Type--Male, No. 14678, U.S.N.M., Orizaba, Mexico, November, 1911 (R. Müller).

CAMBOGIA OPERBULA, new species.

Fore wing overspread with purple, the costa irregularly light salmon color, with a rounded area of this color inclosing the discal dot; termen yellow, the purple color produced in the middle; lines darker, faint, narrow and crenulate, an outer and subterminal visible. Hind wing purple on basal third; outer part yellow, with outer and submarginal faint crenulate reddish lines, which join to form a blotch near inner margin; also traces of a mesial line in some specimens. Expanse, $20 \mathrm{~mm}$.

Cotypes.-Four specimens, No. 14679, U.S.N.M., Orizaba, Mexico, September, 1911 (R. Müller); Orizaba, Mexico (Schaus collection); Jalapa, Mexico (Schaus collection), and one without locality (Schaus collection).

The specimen from Jalapa is one of the types of Eois nundina Druce, ${ }^{1}$ but the Costa Rican and Guatemalan specimens are of another species, to which I would restrict Druce's name.

CAMBOGIA SARIA, new species.

Roseate purple; fore wing with the margin yellow, incised in the middle, the purple basal area crossed by five more yellowish bands, all finely waved; discal dot small, black. Hind wing similar, the yellow margin less distinctly incised by purple in the middle, the purple field with less lines, being a subbasal dark one and two outer orange-red ones. Vertex and shaft of antennæ white. Expanse, $18 \mathrm{~mm}$.

Type.-One female, No. 14303, U.S.N.M., Orizaba, Mexico, November, 1910 (R. Müller).

\section{Genus TEPHROCLYSTIA Hübner.}

TEPHROCLYSTIA GLAUCOTINCTA, new species.

Dark gray, the wings with a mossy green tint over the inner half of fore wing and all of hind wing; fore wing with a small dark sharply limited basal area; lines numerous, indistinct, but marked in their inceptions on costa, about eight lines thus shown, the subterminal most distinctly crossing the wing and narrowly limited outwardly by whitish; discal mark round, dark; narrow black terminal line, dentate on the veins. Hind wing with the base dull whitish; two faint dark lines across before the discal dot; three beyond, the outer submacular and followed narrowly by whitish in the dark glaucous margin. Expanse, $20 \mathrm{~mm}$.

Type.-One female, No. 14450, U.S.N.M., Orizaba, Mexico, August, 1911 (R. Müller). 
TEPHROCLYSTIA MOLLIARIA, new species.

Dark gray, smooth and even, only the black discal dot relieved; a faint whitish spot above tornus; outer line indicated by a black strigose shading; a similar row of subterminal markings. Hind wing whitish, grayer along inner margin; a faint discal dot and segment of mesial band near inner margin. Expanse, $18 \mathrm{~mm}$.

Type.-Female, No. 14451, U.S.N.M., Misantla, Mexico, September, 1911 (R. Müller).

\section{Genus MELEABA Walker.}

MELEABA URANIA, new species.

White; fore wing with long transverse black strigæ, some of the basal ones crossing the wing completely; a straight median transverse brown shaded line and another at outer third, the pair converging toward inner margin; terminal strigæ shorter, though in part confluent into long lines. Hind wing with an emargination above middle of outer margin, below which is an orange patch containing two or three black dots; a brown line from middle of costa runs outward nearly to the orange patch, then bends roundedly at right angles to inner margin; brown mesial streaks to the transverse line; a number of long black strigæ on apical area; a fine terminal black line. Expanse, $21 \mathrm{~mm}$.

Cotypes.-Male and female, No. 14680, U.S.N.M., Popocatepetl Park, Mexico, 9,500 to 11,500 feet, June, 1906 (W. Schaus).

MELABA ANTITHETES, new species.

Forewing densely irrorated with brown over an ocherous ground, leaving two broad white lines and a discal dot; inner line oblique from inner fourth of costa to middle of inner margin, slightly swollen centrally and excurved below; outer line from outer fourth of costa to tornus, its lower half slightly arcuated inward; discal dot small, narrow; a pale shading runs from apex downward to about middle of wing subterminally, beyond which the brown shadings are darker. Hind wing with an emargination above middle of outer margin, below which is an orange patch containing two black dots; general surface white, but with a dark shading from the brown strigæ below showing through; a faint brown mesial line, bent at right angles; a shaded brown terminal line; a diffuse subterminal one, running inside of the orange patch. Expanse, $21 \mathrm{~mm}$.

Cotypes.-Male and female, No. 14681, U.S.N.M., Popocatepetl Park, Mexico, 9,500 to 11,500 feet, June, 1906 (W. Schaus). 


\section{Genus TACHYPHYLE Butler.}

TACHYPHYLE AGANAPLA, new species.

Rather dark green; vertex of head white; on forewing a straight white line from costa before apex to outer third of inner margin; a black point at apex and a discal point. Hind wing with the white line a little broader, mesial, straight, with a faint darker inward edging; a black discal point. Expanse, $30 \mathrm{~mm}$.

Type.-One female, No. 14455, U.S.N.M., Misantla, Mexico, September, 1911 (R. Müller).

\section{Genus ANISODES Guenée.}

\section{ANISODES POLIOTARIA, new species.}

Light gray, finely dark-irrorate on a pale gray ground; lines slender, blackish, denticulate; inner line angled subcostally; discal dot white, small; mesial line finely denticulate, oblique; outer line dotted at the ends of the denticulations, not as strong as the mesial line; terminal line slender, broken by white dots between the veins. Hind wing similar, the inner line absent; discal dot in a black ringlet. Expanse, $28 \mathrm{~mm}$.

Cotypes. -8 specimens, No. 14519, U.S.N.M., Tehuacan, Mexico, June, 1910; June, August, September, 1911 (R. Müller).

\section{Genus C $A$ NOCHARIS Hulst.}

CANOCHARIS OUDEN, new species.

Smooth powdery gray, shining silky, almost unmarked; inner line slender, dark, faint, angled subcostally; outer line denticulate, followed by a whitish shade in the cusps. Hind wing similarly colored, scarcely lighter; a few dark scales above tornus. Expanse, $21 \mathrm{~mm}$.

Cotypes.-Males, No. 14520, U.S.N.M., Tehuacan, Mexico, September, 1911 (R. Müller); Sierra de Guerrero, Mexico, October, 1911 (R. Müller).

\section{Genus SCIAGRAPHIA Hulst (TEPHRINA Guenée).}

SCIAGRAPHIA DECEPTRIX, new species.

Whitish gray, sparsely irrorate; terminal field washed with purplish and cut by a finely wavy white subterminal line; basal area with a little purplish tint; inner line slender, broken, powdery, black, marked on the costa; mesial line marked by a perpendicular brownblack dash on costa, faintly traceable across the wing, with a strong inflexure across submedian; outer line angled subcostally, gently curved below, black, marked on costa, fine and geminate below the bend, followed by a black longitudinal dash at vein 4 , with brown 
below it; a slender terminal black line. Hind wing with brownish tint, finely irrorated; an inner and an outer mesial slender brown line, with small discal dot between them; a series of submarginal cloudings, largest toward apex. Expanse, $20 \mathrm{~mm}$.

Type.-One male, No.14456, U.S.N.M., Tehuacan, Mexico, August, 1911 (R. Müller).

\section{Genus SEMIOTHISA Hübner.}

SEMIOTHISA PHANEROPHLEPS, new species.

Whitish gray, irrorate with brown, the irrorations tending to gather in groups; margins of the wings irregularly shaded with purple-gray; on fore wing cut by a line of the ground color from apex and a patch on middle of outer margin; on hind wing the purplish is restricted to the area above the marginal projection; fore wing with subbasal and inner lines, slender, brown-black, curved; mesial line similar, widened and shaded below, with projections at veins 1 and 2 ; an obliquely placed discal ringlet filled with yellowish; discal venules lined with yellowish; outer line starting in the costal shade, excurved, then gently incurved, very indistinct except between veins $2-5$, where it forms two velvety brown cusps; a small velvety brown spot between veins 2-3, a large one between 3-4 and a small one above vein 4 . On the hind wing a line close to base; a straight inner mesial line; discal ringlet nearly occluded; outer line coarsely waved, distinct, followed by velvety brown patches as on the fore wing. Expanse, $25 \mathrm{~mm}$.

Type.-One male, No. 14457, U.S.N.M., Misantla, Mexico, August, 1911 (R. Müller).

Also a male and female from Jalapa, Mexico (Schaus collection), obviously the same but rubbed. The female lacks the velvety patches beyond the outer line, which is more distinct; the marginal purplish shade is irrorated with yellowish.

\section{Genus PHYSOSTEGANIA Warren.}

PHYSOSTEGANIA MELANORRHCA, new species.

Creamy white; fore wing powdered with brown, the lines in the same brown powdering, defined by bands of the ground color on their outer sides; inner curved; median and outer straight, oblique; subterminal straight and erect; three brown costal marks at the inceptions of the three lines. Hind wing with some brown powdering, especially along inner margin, indistinctly defining mesial, outer and subterminal lines on inner half of wing. Male with the anal segment deep black. Expanse, $22 \mathrm{~mm}$.

Cotypes.-Male and female, No. 14682, U.S.N.M., Zacualpan, Mexico, June, 1910, and August, 1909 (R. Müller). 
Two other males have the genitalia contracted and no trace appears of the black anal tuft, except by dissection. Male and female, Popocatepetl Park, Mexico, 8,000 feet, June, 1906 (W. Schaus); Iguala, Guerrero, Mexico, June, 1906 (W. Schaus).

\section{Genus DEILINIA Hübner.}

DEILINIA GRACIOSA, new species.

White, the wings sparsely irrorated with pale gray; the irrorations are arranged irregularly in transverse lines and are partly confluent; an irregular clear space of the ground color represents the inner line; a more distinct one the outer line, its inner edge indicated by a straight line of confluent irrorations; an indistinct space for subterminal line. Hind wing similarly marked. Expanse, $30 \mathrm{~mm}$.

Cotypes.-Two males, one female, No. 14683, U.S.N.M., Popocatepetl Park, Mexico, 8,000 feet, June, 1906 (W. Schaus); Zacualpan, Mexico, June, 1910 (R. Müller).

\section{Genus DIGONODES Warren.}

DIGONODES MAIDIENA, new species.

Wings with the outer margin crenulate, the fore wing projecting at the ends of veins 4 and 6 . Wood-brown, the color only appearing distinctly at anal angle, all the rest overlaid with blackish, minutely powdery and irrorate; lines gently curved, crenulate, black, single, the outer marked with white points on the veins; discal dot a white point in a black ring; a straight light shade from apex to tornus, nearly touching the outer line centrally. Hind wing similar to fore wing, darkly shaded, lighter at base and margin; an outer mesial black crenulate line; a light space at tornus, sharply limited within. Expanse, $36 \mathrm{~mm}$.

Type.-One female, No. 14458, U.S.N.M., Tehuacan, Mexico, August, 1911 (R. Müller).

\section{Genus SELENIA Hübner.}

SELENIA ISMALIDA, new species.

Fore wing gray, mottled-strigose with olivaceous, the median space filled with olivaceous on its lower two-thirds; three costal streaks, at the inceptions of the lines; inner and mesial lines olive-brown, lost below in the shading, the inner line traceable by its pale border; outer line dark, with a light border, strongly angled subcostally, shallowly emarginate between veins 2 and 4; a costo-subapical quadrate olive-brown patch. Hind wing with the discal area faintly yellowish, mottled, with faint discal dot; a curved outer line, relieved by yellowish beyond, the margin broadly darker gray. Expanse, $25 \mathrm{~mm}$. 
Type.-Male, No. 14521, U.S.N.M., Zacualpan, Mexico, October, 1910 (R. Müller).

A female, which I think belongs to this species, is brown-gray, without the dark shading in median space; inner and median lines brown, distinct, both strongly angled in the middle; marginal space shaded with purplish. Hind wing with the disk more strongly yellow, the purplish freckles distinct; outer line brown-gray, the margin and an area along inner margin brown. Expanse, $30 \mathrm{~mm}$.

Zacualpan, Mexico, October, 1911 (R. Müller).

SELENIA RICOCHETTA, new species.

Brown, the males with a purplish tint, the females red-brown; wings irrorate with darker brown; lines brown, the inner coarsely crenulate and excurved in cell; outer sharply angled subcostally and a little irregular below; mesial line lighter brown and less distinct than the others, sharply angled beyond the cell, running very close to the outer line after the angulation; discal mark narrow, faint, somewhat leaden-tinted. Hind wing with the outer line distinct, preceded by a brown shade that represents the mesial line; purplish clouding subterminally more distinct than on fore wing, representing a pale submarginal line. Expanse, 32-37 mm.

Cotypes.-Three males and three females, selected from a series, No. 14684, U.S.N.M., Jalapa and Coatepec, Mexico (Schaus collection); Orizaba, Mexico, September 2 and June, 1908 (R. Müller).

Genus HYGROCHROMA Herrich-Schäffer.

HYGROCHROMA HYALOPUNCTA, new species.

Male purplish brown, female reddish brown, the wings of the male scarcely falcate at apex, those of the female strongly so with depressed costa. Fore wing with inner line slender, dark, wavy, produced in the cell; median shade distinct, dark, crossing both wings; discal mark narrow or punctiform, hyaline on both wings; a costo-subapical creamy white patch, more drawn out in the female than in the male; outer line slender, dark, faint; a dark shade upward from tornus. Both wings strigose in darker shade, the hind wing with terminal dark shade on lower half. Expanse, $42-47 \mathrm{~mm}$.

Cotypes.-One male, two females, No. 15230, U.S.N.M., Orizaba, Mexico (R. Müller); Jalapa, Mexico (Schaus collection).

The specimens from the Schaus collection were labeled nondina Druce, but they differ from that especially in the hyaline discal mark. 
Genus TEPHRINOPSIS Warren.

TEPHRINOPSIS CONIARIA, new species.

Pale straw color, powdered with brown; fore wing with a large discal dot and four bands of powdery brown; inner one broken centrally; mesial one nearly continuous, but more distinct on costa and inner margin; outer one represented by marks on the costa and margin; subterminal one distinct, broad, preceded by a lighter shade of the ground color. Hind wing with mesial line strongly angled in its middle, its lower limb distinct, its upper limb obsolete; a submarginal pale shade, defined by absence of brown irrorations. Expanse, $21 \mathrm{~mm}$.

Type.-One female, No. 14452, U.S.N.M., Orizaba, Mexico, August, 1911 (R. Müller).

The species looks like Microxydia pulverosa Schaus, but it has the lines of the hind wing bent at an angle. It also resembles Tephrina submarcata Schaus, but this also has straight bands on the hind wing.

\section{Genus DIASTICTIS Hübner.}

\section{DIASTICTIS LAMITARIA, new species.}

Light lilacine gray, finely dusted with brown; head and collar dull ocherous shaded; fore wing with the inner line very fine and slender; a small dark discal mark; mesial line just beyond, fine, slender, irregularly waved centrally; outer line similar, straighter, bent outwardly on submedian; subterminal line shaded, with a blotch above vein 5; all the outer lines show dark stains on the costa. Hind wing whitish, freckled with purplish on lower two-thirds; discal dot small; traces of an outer line near inner margin. Expanse, $28 \mathrm{~mm}$.

Type.-One male, No. 14453, U.S.N.M., Cerritos, San Luis Potosi, Mexico, August, 1911 (R. Müller).

Allied to $D$. tenebrosata Hulst.

\section{Genus ANISODES Guenée.}

\section{ANISODES MESOTURBATA, new species.}

Ground color light ocherous brown, shaded and powdered with dark rusty brown except in the outer half of the median space; inner line dark brown, straight, except for a bend at right angles on subcosta; discal mark a minute light point in a dark ring; mesial line dark, shaded, dentate on the veins, bent inward on submedian; outer line nearly resolved into dots on the veins, bent outward subcostally; veins slightly darker outwardly. Hind wing the same except for the inner line; mesial shade just beyond the discal mark; space between it and the outer line pale. Expanse, $28 \mathrm{~mm}$.

Type.-One male, No. 14454, U.S.N.M., Cerritos, San Luis Potosi, Mexico, August, 1911 (R.Müller). 


\section{Genus PHIGALIA Duponchel.}

PHIGALIA CRYPTAPHELES, new species.

Fore wing light gray; inner line double, blackish, curved; mesial line black, distinct and closely followed by a broad parallel grayer, more powdery band; outer line black, broadly broken centrally except for dots on the veins, indistinctly bordered with vinous without; submarginal line whitish, dentate, obscure; apex lightly blackish clouded. Hind wing white, contrasting; some black specks on inner margin; a slender crenulate terminal black line. Expanse, $28 \mathrm{~mm}$.

Cotypes.-Two males, No. 14548, U.S.N.M., Zacualpan, Mexico, October, 1911 (R. Müller).

\section{Genus CENOCALPE Hübner.}

\section{CENOCALPE SISTENATA, new species.}

Light gray with slight carneous tint, sparsely irrorate with black, thinly scaled; a dusky outer band on fore wing, roundedly bent mesially and followed by a whitish shade, obsolete below; a dark mark on the middle of costa. Hind wing without markings. Beneath on fore wing the dark band is repeated in dark scales, the apex is washed with purplish, and a longitudinal streak crosses the purplish field. Hind wing purplish with a dark outer band, running along costa, produced in middle of wing and notched opposite cell; blackish irrorations indistinctly forming a streak directed toward apex. Expense, $26 \mathrm{~mm}$.

Type.-Male, No. 14685, U.S.N.M., Zacualpan, Mexico, December, 1911 (R. Müller).

Near C. morrisata Hulst, but smaller with the dark markings more distinct.

\section{Genus APICIA Guenée.}

APICIA ENTYCHON, new species.

Pale whitish ocherous, more or less shaded with purplish, densely irrorate with purple strigæ; veins narrowly indicated in brown; lines purple-brown, the inner strongly angled on median vein, the outer angled subcostally, its point directed toward apex; a marginal dark line and discal dot; traces of a mesial line on costal area. Hind wing with the veins dark-lined, a straight band across the middle and terminal line; discal dot small and faint. Expanse, 30-33 mm.

Cotypes.-Two females, No. 14686, U.S.N.M., Zacualpan, Mexico, October, 1911 (R. Müller); Cuernavaca, Mexico, June, 1906 (W. Schaus). 


\section{Genus STENACIDALIA Packard.}

STENACIDALIA UNIDENTIFERA, new species.

Gray, finely irrorate, with brownish shadings; basal space coarsely powdered with black scales; inner line black, strongly curved, a little irregular; median space shaded with brown, irrorated with black squamæ; with a brown-black mesial line that starts on costa before middle, forms a loop beyond discal mark and returns obliquely to inner margin at basal third; discal mark small, white, with black bordering scales; outer line black, slightly wavy above, touching the submarginal line in a sharp point, then oblique and coarsely waved to inner margin before middle, forming a larger undulation below with its point on vein 1; submarginal line brown, shaded, even and parallel to outer margin; some brown shading about apex; a terminal broken black line. Hind wing similarly colored, shaded with brown at base; discal dot as on fore wing but fainter; mesial line brown, curved; extra-mesial line black, wavy, with a sharp point near the middle to the submarginal line, white is brown and parallel to the margin; fringe as on fore wing, more strongly crenulate. Expanse, $35 \mathrm{~mm}$.

Cotypes.-Two males, No. 14549, U.S.N.M., Tehuacan, Mexico, May, 1911 (R. Müller); Cuernavaca, Mexico, May, 1911 (R. Müller).

\section{Genus TEPHROSIA Boisduval.}

TEPHROSIA SUPPLANARIA, new species.

Light yellowish gray with a greenish tint; base and cell coarsely powdered with black, in which the inner line is faintly shown, bent subcostally; median line shown as a short black zigzag on costa; discal mark distinct, black, lunate, solid; outer line not far beyond center of wing, black, wavy, broken across the discal venules; a broad shade following it runs down opposite cell and spreads below a little; submarginal line of the ground, edged with black shadings on both sides, wavy-crenulate, a little produced at its upper third, where the following black shade is distinct and touches the margin; a row of marginal black dots. Hind wing pale gray, irrorate with darker gray; a small black discal dot; faint mesial line, most distinct on inner margin; submarginal line rather more distinct, a broken black terminal line. Expanse, $36 \mathrm{~mm}$.

Type.-Female, No. 14550, U.S.N.M., Misantla, Mexico, October, 1911 (R. Müller). 


\section{Family MEGALOPYGIDÆ.}

\section{Genus MESOSCIA Hübner.}

MESOSCIA DUMILLA, new species.

Collar and posterior part of thorax white, disk gray; abdomen brownish, with a large gray anal tuft in the female. Fore wing white, crossed by a broad median brown-gray band, which is cut by white veins; the band starts near apex and runs obliquely almost to base, leaving the costa white above the cell and the base of wing white; the band becomes broad on the inner margin and is excised outwardly; a terminal gray band, running from tornus to about vein 5 . Hind wing white on the disk, the costa and margins gray. Expanse, 22-30 mm.

Type.-Male, No. 14304, U.S.N.M., Misantla, Mexico, May, 1910 (R. Müller); Paso San Juan, State of Vera Cruz, Mexico (Schaus collection).

\section{MESOSCIA EUTECTA, new species.}

Thorax white, collar and pectus black; legs dark gray; thorax tipped with dark gray; abdomen gray above. Fore wing white; a broad dark gray costal stripe, reaching to the cell and stem of veins 7-9; other veins lined with the same color, especially the branches of the median vein; a shade filling in between vein $1 c$ and median below the cell; a shade between vein 1 and inner margin except at extreme base. Hind wing white. Expanse, $29 \mathrm{~mm}$.

Type.-Male, No. 14464, U.S.N.M., Orizaba, Mexico, September, 1911 (R. Müller).

\section{Family ZYGANID E. \\ Genus GINGLA Walker. \\ GINGLA RACONICA, new species.}

Wings semitranslucent, dull black; body black, an orange shading over the patagia and anterior half of thorax. Expanse, $19.5 \mathrm{~mm}$.

Type.-One female, No. 14467, U.S.N.M., Cerritos, San Luis Potosi, Mexico, August, 1911 (R. Müller).

Similar to $G$. thyesta Druce, but the wing-shape and venation are different. In this species the veins of fore wing are all separate; in thyesta 8 and 9 are stalked.

\section{Family LACOSOMID无.}

\section{Genus LACOSOMA Grote.}

LACOSOMA MEDALLA, new species.

Wings pinkish brown, a little grayer on the outer margin of fore wing; an extra-mesial curved brown line, common to both wings; fore wing with a faint, gray, elongate discal mark; outer margin 
scalloped between the veins, and roundedly produced, between veins 2 and 4 ; fringe narrowly white. Expanse, $35 \mathrm{~mm}$.

Type.-Female, No. 15231, U.S.N.M., Cuernavaca, Mexico, June, 1906 (W. Schaus).

Allied to Cicinnus lygia Schaus.

LACOSOMA JULIETTA, new spesies.

Fore wing pinkish brown over the disk, shading to red in the cell, the margins broadly gray; lines obsolete; discal mark elliptical, blackish, surrounded by gray; outer margin smooth, produced between veins 2 and 4 , the apex sharp. Hind wing gray, irrorated with a few coarse dark specks, the discal mark smaller than on fore wing, but similar. Expanse, $27 \mathrm{~mm}$.

Type--Male, No. 15232, U.S.N.M., Misantla, Mexico, July, 1912 (R. Müller). Closely allied to L. otalla Schaus and L. rosea Dognin.

\section{Family THYRIDIDÆ.}

\section{Genus MESKEA Grote.}

MESKEA HORROR, new species.

Fore wing fawn color, shaded with blackish in the cell and with gray terminally; several series of small blackish dots subcostally and in the cell, becoming dense and bordering the veins terminally. Hind wing with a white submarginal band, bent toward the base above tornus, the basal area shaded with black, the termen gray, with dark dots. Expanse, male $30 \mathrm{~mm}$.; female $43 \mathrm{~mm}$.

Type.-One male, No. 13370, U.S.N.M., Jalapa, Mexico, May, 1908 (R. Müller); one male, Cordoba, Mexico (W. Schaus); three females, Cuernavaca, Mexico, June and July, 1906 (W. Schaus).

Similar to M. dyspteraria Grote, but the hind wing drawn out with a sharp point, the outer margin distinctly emarginate.

MESKEA SUBAPICULA, new species.

Cinereous yellowish, coarsely irrorate with gray, the irrorations indistinctly arranged in curved transverse bands on outer part of wing; a broad longitudinal black streak below the outer part of the cell. Hind wing with long apical point, strigose and shaded with gray, forming broad bands through the middle and along outer margin. Abdomen blackish gray. Expanse, 19-21 mm.

Cotypes.-Two specimens, No. 14687, U.S.N.M., Oaxaca, Mexico, August, 1911 (W. D. Hunter), labeled as "injuring cotton."

\section{Genus DYSODIA Clemens.}

\section{DYSODEA MONAVA, new species.}

Olivaceous gray, the bases of both wings infiltrated with straw yellow, covered with dark dense striæ; fore wing with small trian- 
gular white spot in cell, beyond which a dark band, broad on costa; a narrow submarginal line, partly attached to the small reticulations; termen narrowly dark. Hind wing with the spot in the cell large with an indentation outwardly, all the area beyond it to the termen dark; submarginal line indistinct and broken. Body parts yellowish, olivaceous gray. Expanse, $23 \mathrm{~mm}$.

Type.-One male, No. 14305, U.S.N.M., Zacualpan, Mexico, June, 1910 (R. Müller).

\section{Family PYRALID瓜. \\ Subfamily PYRAUSTIN AE. \\ Genus PHLYCT ENODES Guenée. \\ PHLYCT AENODES CUPREICOSTALIS, new species.}

Lustrous yellowish, the wings semitranslucent; collar and costa cupreous brown; lines slender, brown-gray; inner line even, gently curved; orbicular and reniform gray-brown, solid; outer line gently outcurved, then running inward on vein 2 to a point below origin of vein 3 , then straight to inner margin; termen narrowly cupreous brown; fringe gray-brown. Hind wing with a single mesial line, similar to the outer line of fore wing, more sharply angled on its bend on vein 3, the reentrant part obsolete; fringe as on fore wing. Expanse, $27 \mathrm{~mm}$.

Cotypes.-Male and female, No. 14449, U.S.N.M., Guadalajara, Mexico (Schaus collection); Sierra de Guerrero, Mexico, August, 1911 (R. Müller).

\section{Genus NOMOPHILA Hübner.}

NOMOPHILA IRREGULALIS, new species.

Fore wing powdery gray, with a somewhat carneous underground, darker shaded along the costa; inner line slender, blackish, irregularly dentate; orbicular a dot; reniform a black crescent; outer line strongly excurved over cell and bent on vein 1 , irregularly dentate, the points a little pronounced with a slight tendency to form dots; a terminal slender black line. Hind wing silky, whitish, with faint carneous tint. Expanse, $27 \mathrm{~mm}$.

Cotypes.-Male and female, No. 14497, U.S.N.M., Tehuacan, Mexico, September, 1911 (R. Müller).

\section{Genus PYRAUSTA Schrank.}

\section{PYRAUSTA MINIMISTRICTA, new species.}

Fore wing dark gray, slightly or completely washed with crimson; an outer broad pale gray band, oblique, a little inflexed below; a faint light ray outwardly from base. Hind wing dark fuscous, a little lighter toward base. Expanse, $14 \mathrm{~mm}$. 
Cotypes.-Three specimens, No. 14448, U.S.N.M., selected from a series, Tehuacan, Mexico, October, 1910, September, 1911 (R. Müller).

PYRAUSTA XANTHOCRYPTA, new species.

Vertex and upper aspect of palpi dull ocherous partly hidden by gray; fore wing dark gray, the lines faintly relieved, dark, with whitish edges; inner slightly curved, its inner whitish border faint; a dark dot in the cell and one at the end, a whitish streak between them; outer line straight, then strongly incurved on its lower third, upward a little, then straight to inner margin, its outer whitish edging distinct. Hind wing fuscous with more or less distinct outer flexuous dark line. Expanse, 17-18 mm.

Cotypes.-Four specimens, No. 14692, U.S.N.M., Mexico City, Mexico, July, 1909 (R. Müller); San Diego, California, May 7 and 20, June 22, 1911 (G. H. Field).

One of the cotypes is in Mr. Field's collection.

\section{Genus CROCIDOLOMIA Zeller.}

\section{CROCIDOLOMIA PALINDIALIS Guenée.}

Spilodes palindialis GuenÉE, Spec. Gen., Lep., vol. 8, 1854, p. 380.

Botys pyrenealis WaLKer, Cat. Brit. Mus., pt. 18, 1859, p. 580.

Botys medonalis Walker, Cat. Brit. Mus., pt. 18, 1859, p. 599.

Crocidolomia palindialis Hampson, Proc. Zool. Soc. Lond., 1898, p. 758.

Evergestis dyaralis Fernald, Journ. N. Y. Ent. Soc., vol. 9, 1901, p. 49.

Evergestis dyaralis Dyar, Proc. Ent. Soc. Wash., vol. 4, 1901, p. 460.

Evergestis dyaralis FERNALD, Bull. 52, U. S. Nat. Mus., 1903, p. 380, No. 4333.

This species is of wide tropical distribution. I have several specimens before me from Mexico, and have collected it in southern Florida.

CROCIDOLOMIA OCHRITACTA, new species.

Fore wing shining olive brown; inner line fine, blackish, obsolescent, angled in the middle, forming a blotch on inner margin; discal margin lunate, outlined finely in blackish, indistinct; outer line punctiform, angled subcostally, followed by a faint lighter shade; a terminal row of black dashes, emphasized at apex and tornus, the former outwardly oblique minutely, the latter with a light spot in the otherwise dark fringe. Hind wing brownish semitranslucent; a broad even outer black band; fringe dark ocher, except at apex and tornus where it is black. Expanse, $27 \mathrm{~mm}$.

Type.-Male, No. 15233, U.S.N.M., Orizaba, Mexico, June, 1912 (R. Müller).

\section{Genus POLYGRAMMODES Guenée.}

POLYGRAMMODES BEUSCALIS, new species.

Light brown with a reddish tinge, the margins grayish shaded; fore wing with the inner line grayish black, oblique to submedian, then in- 
curved; cell hyaline, with blackish central spot and double bar at the end; outer line gray, crenulate, central segment dislocated outward between veins 3 and 5 ; a subterminal wavy shade. Hind wing with the cell hyaline, a small central black dot and outward reniform mark like the fore wing but with some hyaline area beyond it; outer line and margin as on fore wing. Expanse, $47 \mathrm{~mm}$.

Type.-Male, No. 15234, U.S.N.M., Misantla, Mexico, June, 1912, (R. Müller).

Apparently allied to $P$. rufinalis Hampson from Venezuela. ${ }^{1}$

EDIA, new genus.

Palpi porrect, rostriform, the third joint downward curved and hidden in hair, extending about the length of the head in front. Fore wing trigonate, veins 2 to 5 well separated, the lower part of cell rounded; veins 6,7 well separated, well below the apex of the cell; 8,9 stalked, 10 close to the base of the stalk, 11 far removed from apex of cell. Hind wing with the cell produced on its lower half, veins 2 to 5 well separated, 6, 7 stalked from the upper angle of cell, 7 broadly anastomosing with 8 beyond its separation from 6 .

Allied to Protrigonia Hampson. ${ }^{2}$

Type-species.-Edia microstagma, new species.

EDIA MICROSTAGMA, new species.

Fore wing light gray; a black speck at base of costa; inner line curved, black, broad, distinct, shaded outwardly, an inward notch below median vein, an oblique dash slightly within on inner margin, running out on a long oblique scale-tooth; a minute whitish spot in cell, surrounded by, black; a brown shading beyond, diffused outwardly; apex broadly brown shaded, in which are black streaks on the veins with shorter white ones above and in the fringe. Hind wing fuscous with a faint outer curved dark line followed by whitish blotches toward tornus. Expanse, 19-20 mm.

Cotypes.-One male, one female, No. 15235, U.S.N.M., Tehuacan, Mexico, June, 1912 (R. Müller); Huachuca Mountains, Arizona, July 24-30 (Dr. W. Barnes). The Arizonan specimen is larger and lighter than the Mexican one, the brown shade on middle of fore wing is less extensive and the fringes of hind wing are white. A second specimen from Arizona has been in the hands of Prof. C. H. Fernald for many years (labeled 108) and will ultimately rest in Doctor Barnes' collection.

Subfamily CRAMBIN AE.

Genus DORATOPERAS Hampson.

DORATOPERAS SYSTRAPEGUS, new species.

Body and fore wing light creamy yellow, the fore wing sparsely irrorated with black; a rather large black discal mark; lines brown, 
faint; first line beyond the middle, very irregular, strongly excurved over cell and dentate on the veins; outer line submarginal, strongly dentate on the veins; a row of terminal black dots. Hind wing whitish with terminal dusky black dashes. Expanse, $53 \mathrm{~mm}$.

Cotypes.-Two males, No. 14447, U.S.N.M., Misantla, Mexico, August, 1911 (R. Müller); Omai, British Guiana (W. Schaus).

\section{Subfamily HPIPASCHIIN AE.}

Genus TIOGA Hulst.

TIOGA BUNNIOTIS, new species.

Basal area broad, ocherous, shading to dark brown outwardly, finally black just before the white inner line, which is slightly excurved below the middle; a black costal dash at base; rest of the wing light gray; outer line white, finely denticulate, edged within by black narrowly; terminal space shaded with blackish especially apically. Hind wing pale fuscous, shading to blackish along the margin rather darker in the female; a terminal black line; fringe light at base. Expanse, 20-26 mm.

Cotypes.-Three males, one female, No. 14688, U.S.N.M., Orizaba, Mexico, November, 1911 (R. Müller); Orizaba, Mexico (Schaus collection); Jalapa, Mexico (Schaus collection).

\section{PARANATULA, new genus.}

Palpi upturned, in the male with a long thick basal process, hairy on its upper side. Fore wing with veins 3, 4, 5 from the angle of the cell, 4, 5 closely approximated for one-fourth their length, 6 from the upper angle of the cell, 7 to 9 stalked, 10 free but close to the stalk of 7-9 at base. Hind wing with vein 3 from the lower point of the cell, 4, 5 stalked for half their length, 6 from the cell, 7 anastomosing with 8 .

Type-species.-Paranatula zographica, new species.

PARANATULA ZOGRAPHICA, new species.

Fore wing violaceous gray, the basal and terminal areas light pinkîsh gray; basal area diffused outwardly, a narrow black dash on inner margin at base and one outwardly below center of cell; traces of an irregular black mesial line; outer line black, distinct, curved in a gentle arc from outer third of costa to outer fourth of inner margin, limiting the mesial gray area; faint clouded gray subterminal shade. Hind wing fuscous tinged outwardly, the veins darker, fringe pale. Expanse, $17 \mathrm{~mm}$.

Cotypes.-One male, two females, No. 15236, U.S.N.M., Aroa, Venezuela (Schaus collection); Orizaba, Mexico, June, 1912 (R. Müller); Jalapa, Mexico (Schaus collection). 
Subfamily PHYCITIN AE.

Genus MELITARA Walker.

MELITARA PARABATES, new species.

Head and thorax dark gray, intermixed with blackish scales; abdomen whitish, the segments gray dorsally. Fore wing light gray, a little shaded with brownish on the inner half; some blackish shading at base; inner line remote from base, black, double, dentate, the outer line the most distinct, with a long tooth in cell and below median vein; a blackish shade-band mesially below cell; discal mark of two joined dots; subcostal veins above the cell black-lined; outer line near the margin, black, strongly dentate, indistinctly doubled outwardly, an inward tooth opposite discal mark, smaller teeth on the discal venules, an inward tooth on vein 1 ; veins in terminal space dark-lined; a row of terminal black dots. Hind wing white, the apex tipped with gray. Expanse, $39 \mathrm{~mm}$.

Type.-Female, No. 14446, U.S.N.M., Cerritos, San Luis Potosi, Mexico, August, 1911 (R. Müller).

Genus EUZOPHERA Zeller.

EUZOPHERA GRISELDA, new species.

Dark blackish gray, without any reddish tint; lines far out, the inner at the middle of wing, whitish, edged with dark gray toward each other, the inner a little irregular and strongly incurved at submedian, the outer finely subdentate, excurved centrally and inward on submedian; discal mark squarish, white. Hind wing whitish, shaded with fuscous along the veins and in a narrow marginal band. Expanse, $26 \mathrm{~mm}$.

Cotypes.-Two females, No. 14551, U.S.N.M., Tehuacan, Mexico, September, 1911 (R. Müller).

\section{EUZOPHERA IMMORELLA, new species.}

Fore wing rather dark gray, powdered with black; inner line black, produced outward into a tooth in the middle, the costal segment forming an oblique thick band; discal mark of two dots conjoined by their inner angles; outer line double, black, oblique, "slightly crenulate and with an inward angle opposite the discal mark. Hind wing whitish, semihyaline, tinged with fuscous on veins and margin. Expanse, $25 \mathrm{~mm}$.

Cotypes.-Two females, No. 15237, U.S.N.M., Tehuacan, Mexico, July, 1912 (R. Müller); Oaxaca, Mexico (Schaus collection), the latter labeled "Euzophera sp., not in B. M." in the writing of Sir G. F. Hampson. 
BALLOVIA, nev genus.

With the characters of Pristarthria Ragonot, ${ }^{1}$ but the antennæ of the male have only a single tooth in the basal sinus.

Type-species.-Ballovia cistipennis, new species.

BALLOVIA CISTIPENNIS, new species.

Fore wing gray, with more or less of a whitish shade through the middle; a large rounded black spot in the center of the wing in the position of the inner line, outlined by the whitish shading, which in dark specimens forms an annulus about it; discal mark lunate, dark, faint; outer line whitish, curved inward below costa and at submedian fold, a dark gray shade within it in pale specimens, widening below; subterminal line whitish, preceded and followed by gray dots, which are illy contrasted in dark specimens. Hind wing whitish, translucent, a little yellowish tinted on margin; inner margin folded and swollen in the male, covering yellowish androconia. Expanse, 20-21 mm.

Cotypes.-Four males, one female, No. 15238, U.S.N.M., Wildey, Barbados, October 31, 1911 (H. A. Ballou, Commissioner of Agriculture, Imperial Department of Agriculture for the West Indies), larvæ injurious to cowpeas.

\section{Family COSSID丑.}

\section{Genus GIVIRA Walker.}

GIVIRA GABRIEL, new species.

Dark gray. Fore wing pale gray on the central third, brownish gray at base and in a large area over the discal venules; a semilunate deep brown bar, touching the costa subapically, surrounded by white; a similar upright angular marking on middle of inner margin, nearly reaching costa; a slight olivaceous tint in the shading along inner margin; reticulations indistinct, dotted along the costal area, very fine on lower part of wing. Hind wing whitish gray, finely powderyreticulate. Expanse, $34 \mathrm{~mm}$.

One male, Cerritos, San Luis Potosi, Mexico, August, 1911 (R. Müller).

Type.-No. 14468, U.S.N.M.

\section{GIVIRA FELICOMA, new species.}

Reddish brown, the costa and outer area of wing gray, all with dense, short, clouded gray strigæ; a dark cloud at end of cell, followed by brighter reddish; dark also between the discal venules, which are themselves reddish lined. Hind wing whitish, with but few gray strigæ. Expanse, $36 \mathrm{~mm}$. 
Type.-Male, No. 15239, Cuernavaca, Mexico, April, 1912 (R. Müller).

Close to G. flavescens Dognin, but more densely strigose, especially on the outer half of wing.

Genus ARBELA Moore.

ARBELA NAIDA, new species.

Fore wing brownish gray, the strigæ small and sparse, forming wavy lines on the outer part of wing; a blackish cloud beyond cell; a slender silvery white line along inner margin to middle; a terminal row of black streaks at the terminations of the veins. Hind wing gray, scarcely strigose, with terminal marks as on fore wing. Expanse, $31 \mathrm{~mm}$. Male antennæ simple.

Type--Male, No. 15240, U.S.N.M., Cuernavaca, Mexico, April, 1912 (R. Müller). 

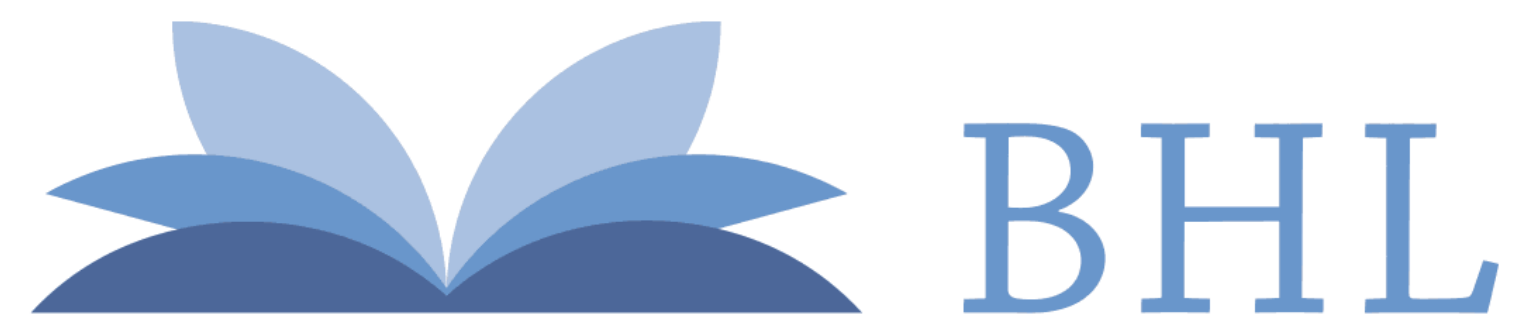

\section{Biodiversity Heritage Library}

Dyar, Harrison G. 1913. "Descriptions of new Lepidoptera, chiefly from Mexico." Proceedings of the United States National Museum 44(1951), 279-324. https://doi.org/10.5479/si.00963801.44-1951.279.

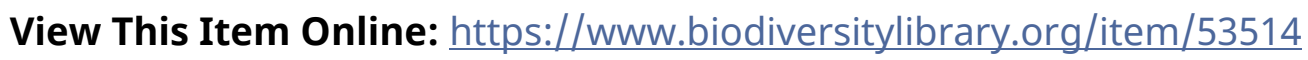

DOI: https://doi.org/10.5479/si.00963801.44-1951.279

Permalink: https://www.biodiversitylibrary.org/partpdf/52476

\section{Holding Institution}

Smithsonian Libraries

\section{Sponsored by}

Smithsonian

\section{Copyright \& Reuse}

Copyright Status: Public domain. The BHL considers that this work is no longer under copyright protection.

This document was created from content at the Biodiversity Heritage Library, the world's largest open access digital library for biodiversity literature and archives. Visit BHL at https://www.biodiversitylibrary.org. 